\title{
Environmental drivers of circum-Antarctic glacier and ice shelf front retreat over the last two decades
}

\author{
Celia A. Baumhoer ${ }^{1}$, Andreas J. Dietz ${ }^{1}$, Christof Kneisel ${ }^{2}$, Heiko Paeth ${ }^{2}$, and Claudia Kuenzer ${ }^{1,2}$ \\ ${ }^{1}$ German Remote Sensing Data Center (DFD), German Aerospace Center (DLR), \\ 82234 Weßling, Germany \\ ${ }^{2}$ Institute of Geography and Geology, University of Würzburg, Am Hubland, 97074 Würzburg, Germany \\ Correspondence: Celia A. Baumhoer (celia.baumhoer@dlr.de)
}

Received: 6 August 2020 - Discussion started: 21 September 2020

Revised: 26 March 2021 - Accepted: 12 April 2021 - Published: 20 May 2021

\begin{abstract}
The safety band of Antarctica, consisting of floating glacier tongues and ice shelves, buttresses ice discharge of the Antarctic Ice Sheet. Recent disintegration events of ice shelves along with glacier retreat indicate a weakening of this important safety band. Predicting calving front retreat is a real challenge due to complex ice dynamics in a data-scarce environment that are unique for each ice shelf and glacier. We explore the extent to which easy-to-access remote sensing and modeling data can help to define environmental conditions leading to calving front retreat. For the first time, we present a circum-Antarctic record of glacier and ice shelf front change over the last two decades in combination with environmental variables such as air temperature, sea ice days, snowmelt, sea surface temperature, and wind direction. We find that the Antarctic Ice Sheet area decreased by $-29618 \pm 1193 \mathrm{~km}^{2}$ in extent between $1997-$ 2008 and gained an area of $7108 \pm 1029 \mathrm{~km}^{2}$ between 2009 and 2018. Retreat concentrated along the Antarctic Peninsula and West Antarctica including the biggest ice shelves (Ross and Ronne). In several cases, glacier and ice shelf retreat occurred in conjunction with one or several changes in environmental variables. Decreasing sea ice days, intense snowmelt, weakening easterlies, and relative changes in sea surface temperature were identified as enabling factors for retreat. In contrast, relative increases in mean air temperature did not correlate with calving front retreat. For future studies a more appropriate measure for atmospheric forcing should be considered, including above-zero-degree days and temperature extreme events. To better understand drivers of glacier and ice shelf retreat, it is critical to analyze the magnitude of basal melt through the intrusion of warm Circumpolar
\end{abstract}

Deep Water that is driven by strengthening westerlies and to further assess surface hydrology processes such as meltwater ponding, runoff, and lake drainage.

\section{Introduction}

A safety band of floating ice shelves and glacier tongues fringes the Antarctic Ice Sheet (AIS) (Fürst et al., 2016). Large glacier tongues and ice shelves create buttressing effects, decreasing ice flow velocities and ice discharge (De Rydt et al., 2015; Gagliardini et al., 2010; Royston and Gudmundsson, 2016). The recent large-scale retreat of ice shelf and glacier fronts along the Antarctic Peninsula (AP) and the West Antarctic Ice Sheet (WAIS) indicates a weakening of this safety band (Rott et al., 2011; Rankl et al., 2017; Friedl et al., 2018; Cook and Vaughan, 2010). Calving front retreat can increase ice discharge and hence the contribution to global sea level rise (De Angelis and Skvarca, 2003; Seehaus et al., 2015). Increases in ice discharge occur if ice shelf areas with strong buttressing forces are lost (Fürst et al., 2016). The current contribution of the Antarctic Ice Sheet to global sea level rise is $7.6 \pm 3.9 \mathrm{~mm}$ (1992-2017), but over this study period a strong trend of mass loss acceleration was observed for West Antarctica after ice shelves and glaciers retreated and thinned (IMBIE, 2018). In contrast, there is no clear trend in the mass balance of the East Antarctic Ice Sheet (EAIS). Since the 1990s altimetry measurements have shown a small gain (but with high uncertainties) for the EAIS, with $5 \pm 46$ Gt/yr (1992-2017) (IMBIE, 2018). However, a strong mass loss trend of $-47 \pm 13 \mathrm{Gt} / \mathrm{yr}$ (1989-2017) is calculated 
using the mass budget method (Rignot et al., 2019). Glacier terminus positions along the EAIS experienced a phase of retreat between 1974 and 1990 followed by a phase of advance until 2012. The single exception to this advance in East Antarctica is Wilkes Land, where retreating glacier fronts were observed (Miles et al., 2016).

The coastline of the Antarctic Ice Sheet is defined as the border between the ice sheet and the ocean (Liu and Jezek, 2004), extending along glacier and ice shelf fronts. Throughout this paper, we refer to floating glacier tongues and ice shelves when using the term "glacier and ice shelf front" as well as "calving front". Whether a glacier or ice shelf front advances or retreats depends mainly on four different factors: internal ice dynamics, geometry, external mechanical forcing, and external environmental forcing (Alley et al., 2008; Benn et al., 2007; Cook et al., 2016; Luckman et al., 2015; Walker et al., 2013). The combined influence of those factors make it challenging to create a realistic calving law, making iceberg calving still one of the least understood ice shelf processes (Bassis, 2011). Frontal retreat starts with the formation of a crevasse originating from a strain rate surpassing the yield stress of ice (Mosbeux et al., 2020). For ice shelves and floating glacier tongues, the calving position evolves where crevasses develop into through-cutting fractures (rifts). These ice shelf rifts can propagate further into the ice front or intersect with other rifts, resulting in a tabular iceberg calving event (Benn et al., 2007; Joughin and MacAyeal, 2005), where the extent of the ice shelf and the size of the iceberg are defined by the rift location (Lipovsky, 2020; Mosbeux et al., 2020; Walker et al., 2013). Further boundary conditions such as fjord geometry (Alley et al., 2008; Catania et al., 2018), ice rises and rumples (Matsuoka et al., 2015), and bed topography (Hughes, 1981) influence the stability of the calving margin.

The previously described natural cycle of growth and decay of a glacier or ice shelf (Hogg and Gudmundsson, 2017) can be disturbed by external mechanical and environmental forces. It was found that mechanical forcing arises from tides (Rosier et al., 2014), ocean swell (Massom et al., 2018), iceberg collision (Massom et al., 2015) and tsunamis (Walker et al., 2013), which can destabilize floating ice shelves and glacier tongues initiating iceberg calving (Alley et al., 2008). Glaciers and ice shelves are in direct interaction with the atmosphere and ocean and are hence sensitive to changes in environmental conditions (Vaughan and Doake, 1996; Kim et al., 2001; Domack et al., 2005; Wouters et al., 2015). Environmental drivers can destabilize floating ice tongues and shelves through various oceanically and atmospherically forced processes, causing mechanical weakening and fracturing (Pattyn et al., 2018). Instead of sporadic calving by tabular icebergs (a sign of a natural calving event within the calving cycle), more frequent small-scale calving events can occur as a result of environmental forcing (Liu et al., 2015). Destabilization through atmospheric forcing arises from thinning through surface melt (Howat et al., 2008), hydrofracture (Kopp et al., 2017; Pollard et al., 2015), lake ponding, and lake drainage (Banwell et al., 2013; Leeson et al., 2020). Ocean forcing weakens the floating ice as a result of basal melt inducing thinning and grounding line retreat (Konrad et al., 2018; Paolo et al., 2015; Rignot et al., 2013) as well as by warmer ocean surface water undercutting the ice cliff at the waterline (Benn et al., 2007) by reducing stabilizing fast ice (Larour, 2004) and through enhanced sea ice reduction (Massom et al., 2018; Miles et al., 2016). Environmental forcing on tidewater glaciers has been frequently observed on Greenlandic glaciers (Cowton et al., 2018; Howat et al., 2008; Luckman et al., 2015), but for Antarctica in many regions it is unclear where and at what amount environmental drivers cause calving front retreat (Baumhoer et al., 2018; Pattyn et al., 2018).

Current knowledge on environmentally forced calving front retreat in Antarctica can be summarized by the following studies.

Glacier retreat along the Antarctic Peninsula was first only associated with atmospheric warming (Cook et al., 2016; Mercer, 1978) until more recent studies identified ocean forcing as the main driver (Cook et al., 2016; Wouters et al., 2015). Additionally, the formation of melt ponds on the ice shelf surface has been discussed as an enhancing factor for calving. Meltwater can initiate crevasse propagation, resulting in hydrofracture and ice shelf retreat (Scambos et al., 2000; Scambos et al., 2017). The poleward shift in the west wind drift causes upwelling Circumpolar Deep Water $(\mathrm{CDW})$. This allows warmer ocean waters to reach the bottom of ice shelves, inducing basal melt and ice shelf thinning, as observed in the Bellingshausen and Amundsen sea sectors (Dutrieux et al., 2014; Thoma et al., 2008; Wouters et al., 2015). Basal melt, when combined with a retrograde bed (Scheuchl et al., 2016; Hughes, 1981), has led to a retreat of the grounding line followed by increased ice discharge (Konrad et al., 2018; Rignot et al., 2013), for example at the former Wordie Ice Shelf (AP) (Friedl et al., 2018; Walker and Gardner, 2017). In contrast, the retreat of calving fronts along Wilkes Land (EAIS) has been associated with a reduction in the duration of the sea ice cover (Miles et al., 2016).

The drivers of ice shelf and glacier retreat and advance can be manifold depending on studied variables, time periods, and regions. Therefore, the identification of environmental driving forces for fluctuations in ice shelf and glacier extent is challenging and has been the subject of many discussions in the past. So far, there has not been a comprehensive analysis comparing circum-Antarctic glacier terminus change on a continental scale within uniform timescales (Baumhoer et al., 2018). In this paper, we explore Antarctic calving front change over the last two decades by analyzing Antarctic coastal change (see Fig. 1) and address the question of whether or not environmental drivers forced the observed changes in glacier and ice shelf front fluctuations. We compare changes in Antarctic calving fronts in two decadal time steps (1997-2008 and 2009-2018) to minimize the ef- 
fect of short-term glacier front fluctuations. To identify potential links between calving front retreat and recent changes in the Antarctic environmental conditions, we correlated two decades of glacier change with climate data, including air and sea surface temperature as well as changes in wind direction, snowmelt, and sea ice cover.

\section{Processed and analyzed data sets}

\subsection{Coastlines}

To calculate the decadal retreat and advance of Antarctic glaciers and ice shelves, we use calving front positions of three Antarctic coastline products from 1997, 2009, and 2018. Timewise, we refer to first (1997-2008) and second (2009-2018) decade even though the time periods are 11 and 9 years, respectively, limited by the availability of coastline products. The first coastline product was automatically extracted from the high-resolution Radarsat-1 mosaic by adaptive thresholding and finalized by manual correction (Liu and Jezek, 2004). The Radarsat-1 mosaic imagery was acquired between September and October 1997 with a spatial resolution of $25 \mathrm{~m}$. The entire data set is freely available at the National Snow and Ice Data Center (NSIDC) at https://nsidc.org/data/NSIDC-0103/versions/ 2 (last access: 25 February 2020) (Jezek et al., 2013). Glacier and ice shelf fronts for the year 2009 were manually delineated from the MOA 2009 surface morphology image map acquired during austral summer 2008/2009 (NovemberFebruary) with a spatial resolution of $125 \mathrm{~m}$ (Scambos et al., 2007). This data set is also freely available at NSIDC from https://nsidc.org/data/NSIDC-0593/versions/1 (last access: 25 February 2020) (Haran et al., 2014). The coastline for 2018 was automatically extracted via a fully convolutional network from Sentinel-1 mid-resolution $(40 \mathrm{~m})$ dual-pol imagery (see Methods section). Directly calculating coastal change between these coastline products includes changes in floating calving fronts and grounded ice walls (as shown in Fig. 1) even though the amount of change from grounded termini is small and prone to inaccuracies due to the low spatial resolution of the coastline product from 2009.

\subsection{ERA5 reanalysis data}

We use ERA5-Land monthly averaged atmospheric reanalysis data for air temperature and snowmelt information (Copernicus Climate Change Service, 2019b). It is the most state-of-the-art reanalysis product from the European Centre for Medium-Range Weather Forecasts (ECMWF), replacing the former ERA-Interim product (Hersbach et al., 2020). Data are available from 1981/1982 to present day at a $9 \mathrm{~km}$ spatial resolution. As ground-based meteorological observations are scarce over the Antarctic continent, we decided to use the reanalysis data even though modeled data are less accurate compared to in situ measurements. Studies compar- ing in situ observations to modeled data prove that ERA5 surface air temperature ( $2 \mathrm{~m}$ temperature) outperforms the former ERA-Interim product. ERA5 temperature data have the ability to capture annual variability and the magnitude of temperature change over the Antarctic Ice Sheet (Tetzner et al., 2019; Gossart et al., 2019). The mean absolute error is $2.0^{\circ} \mathrm{C}$, with higher accuracies in the coastal areas and less accurate results in the interior of the ice sheet (Gossart et al., 2019). Tetzner et al. (2019) reports much higher accuracies for the Antarctic Peninsula, with a mean absolute error of $-0.13{ }^{\circ} \mathrm{C}$. Compared to the mean, the variability in temperature is captured with high accuracy at a mean Pearson correlation coefficient of 0.98 (Gossart et al., 2019; Tetzner et al., 2019). We divided temperature measurements into the cooler half ("winter": April-September) of the year and warmer half ("summer": October-March) to separate the environmental forcing for different seasons.

Snowmelt data should be handled with care as accuracy assessments for the ERA5-Land snowmelt product were not yet performed. Surface mass balance (SMB) data including modeled snowmelt data were found to slightly underestimate the SMB (Gossart et al., 2019). Snowmelt is calculated within the summer months December, January, and February, when most melt occurs. The amount of snowmelt is calculated in millimeters of water equivalent ( $\mathrm{mm}$ w.e.) per day.

The Antarctic continent is circled by weak and irregular easterly winds driven by high-pressure areas over the interior of the Antarctic continent created by cold and dry air. Easterlies weaken in the case of a positive Southern Annular Mode (SAM) as the west wind drift shifts poleward. In order to assess those changes in wind direction, we use ERA5 monthly averaged zonal (west to east) wind speed estimations at $10 \mathrm{~m}$ above the surface with a lateral resolution of approx. $31 \mathrm{~km}$. ERA5 captures the spatial variability in near-surface wind speed but underestimates strong winds and coastal winds, whereas the wind speed over the interior is captured very accurately during summer (Gossart et al., 2019). Over the ocean, ERA5 annual mean zonal wind speed is considerably underestimated compared to ASCAT (Advanced Scatterometer) observations (Belmonte Rivas and Stoffelen, 2019). Overall, the mean absolute error over the continent is $2.8 \mathrm{~m} / \mathrm{s}$, with high variance in space and time, but an accurate representation of the annual variability in zonal wind speed is achieved (Gossart et al., 2019). ERA5 monthly averaged data on single levels are freely available at the Copernicus Climate Change Service Climate Data Store (CDS) (Copernicus Climate Change Service, 2019a). Zonal wind was calculated for the summer months (DJF) because easterly winds show a weakening trend during summer but not throughout the entire year (Hazel and Stewart, 2019).

\subsection{Sea ice days}

The most recent Global Sea Ice Concentration Climate Data Record (Version 2) (Lavergne et al., 2019) was downloaded 

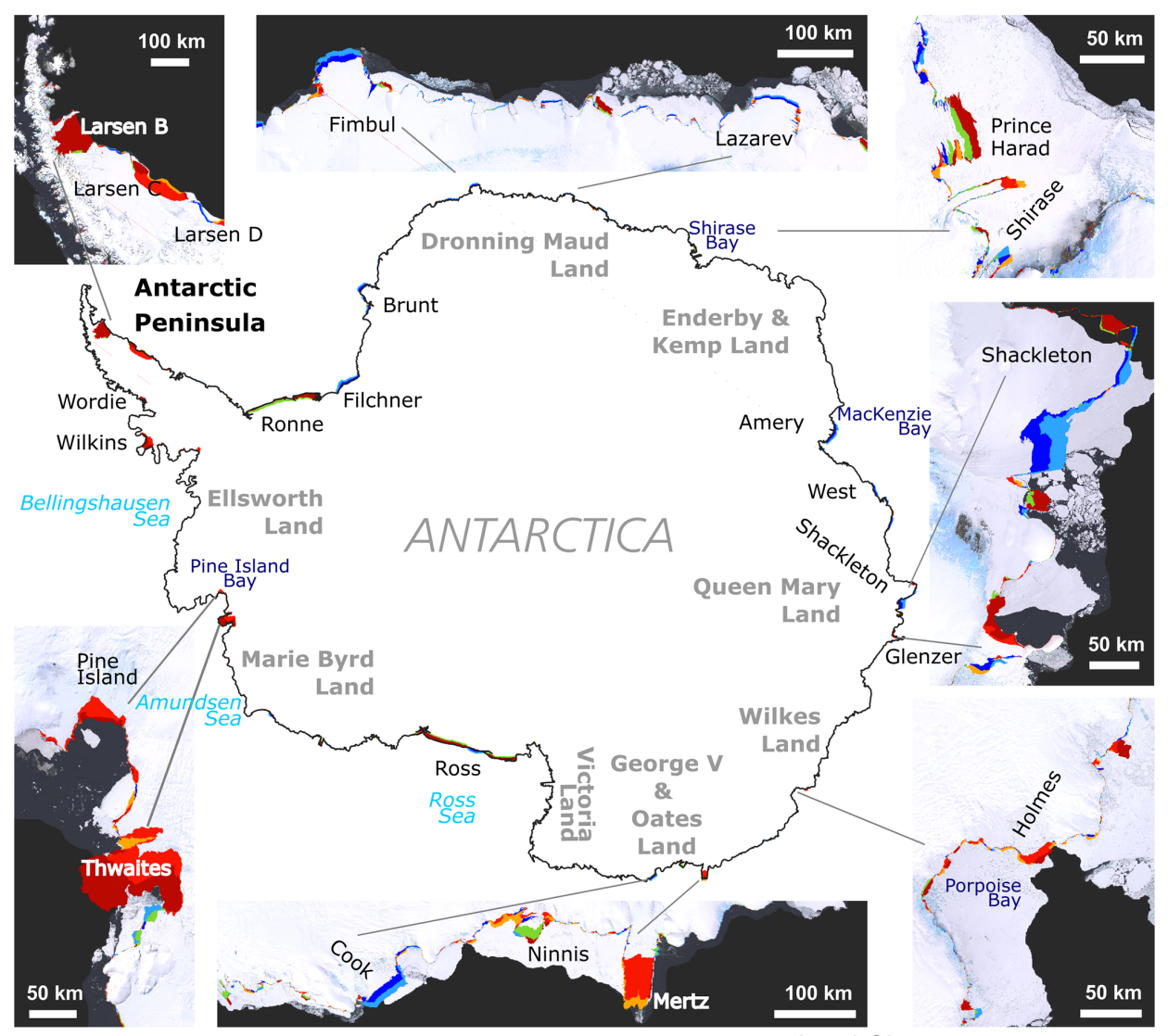

Areal Changes
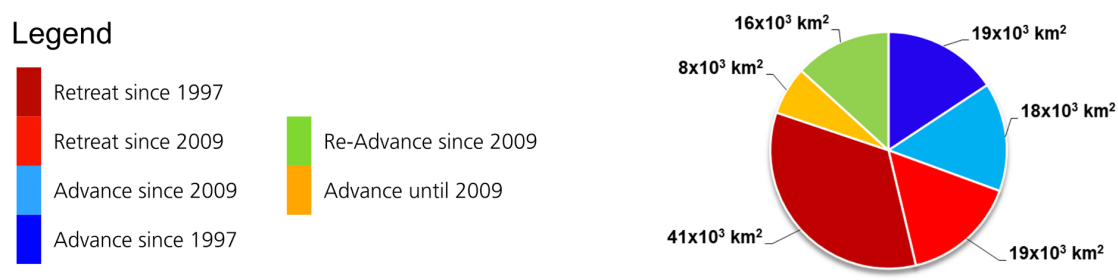

Figure 1. Coastal change in Antarctica between 1997 and 2018 with enlarged views (counterclockwise) for Larsen C Ice Shelf, Pine Island Bay, Oates Land, Wilkes Land, Shackleton Ice Shelf, Shirase Bay, and Dronning Maud Land. Colors indicate the timing of retreat and advance. The pie chart visualizes losses and gains in the area of the Antarctic Ice Sheet with regard to the indicated year. Labels of coastal sectors are shown in gray, seas in light blue, bays in dark blue, and ice shelves and glaciers in black and white fonts. Background: LIMA Landsat Mosaic.

from the Ocean and Sea Ice Satellite Application Facility (OSI SAF, 2017). We used the daily product (OSI-450, OSI430-b) during sea ice months April through October, in line with previous studies (Massom et al., 2013; Miles et al., 2016). The product covers the time period 1982 to 2018 and is derived from passive microwave data acquired by Nimbus 7 and Defense Meteorological Satellite Program (DMSP) satellites. The final sea ice concentration is computed by the passive microwave data in combination with ERA-Interim data. The standard deviation of mismatch between OSI products and ice chart analysis on sea ice concentration is $8 \%$ for ice and open water during winter (JJA). The trend in sea ice extent is very similar between OSI and ice chart products (Brandt-Kreiner et al., 2019), which allows the assumption of a very accurate data set. The product has a resolution of $25 \mathrm{~km} \times 25 \mathrm{~km}$. In order to calculate actual sea ice days, we count each pixel per day with a sea ice concentration higher than $15 \%$ as suggested by previous studies (Miles et al., 2016; Massom et al., 2013). During the early acquisition years data gaps occur, and second-daily acquisitions exist until mid 1987. In this case, we multiplied the monthly available sea ice days by the proportional number of missing days. We decided not to use data for the year 1986 as data for 
entire months were missing, and mean sea ice days per year could not be calculated accurately.

\subsection{Sea surface temperature}

Sea surface temperature measured by satellite sensors is also provided by the CDS (Copernicus Climate Change Service, 2019a). The most up-to-date product Level 4 (Version 2) consists of multiple satellite observations from the NOAA, ERS (European Remote Sensing Satellites), Envisat, and Sentinel3 satellites, with a $0.05^{\circ}$ gridded resolution (approx. $5.5 \mathrm{~km}$ ). We calculated surface temperatures only for the months with little to no sea ice cover (October-March). This reduces errors over sea ice, where the thickness and concentration of sea ice can account for large measurement errors (Kwok and Comiso, 2002). Uncertainties in Level 4 data vary depending on the year of acquisition and latitude of measurement. The median difference compared to in situ drifter measurements is up to $-0.4{ }^{\circ} \mathrm{C}$ for low latitudes during the early acquisition years before 1996. Afterwards the accuracy increases to better than $-0.1{ }^{\circ} \mathrm{C}$ for low latitudes. A stability assessment of the Level 4 product calculated a maximum trend of $0.01^{\circ} \mathrm{C}$ per year (Embury, 2019). A summary of all processed climate variables is given in Table 1.

\section{Methods}

\subsection{Extraction of Sentinel-1 coastline}

We use a modified version of the automatic coastline extraction approach published by Baumhoer et al. (2019) to extract the Antarctic coastline for 2018. To cover the entire Antarctic coastline, 158 dual-pol and 17 single-pol mediumresolution Sentinel-1 scenes were processed. Dual-polarized scenes contain radar backscatter values for the polarizations $\mathrm{HH}$ and $\mathrm{HV}$, whereas single-polarized scenes only include the HH polarization. The coastline was split into 18 zones based on ice flow divides, defining major ice sheet basins after Rignot et al. (2011). For each zone all available scenes acquired during winter months (June-August) in 2018 were selected. Depending on the scene availability, each zone was covered at least by one Sentinel-1 scene and in the best case by three scenes. In case no dual-pol scenes were available, single-pol data were selected. First, each scene was pre-processed (thermal correction, calibration, terrain correction), masked with a coastline buffer of $100 \mathrm{~km}$, and tiled into $780 \times 780$ pixel tiles. The convolutional neural network (CNN) U-Net was used to segment each tile into the class ocean and the class land ice. We trained the U-Net on 15 different Antarctic coastal regions during various seasons with 40036 image tiles from 75 Sentinel-1 scenes. For single-pol scenes we retrained our network for $\mathrm{HH}$-polarized images only. This decreased the accuracy slightly as only one polarization limits the information on surface backscatter characteristics. In the post-processing step the mean of all seg- mented tiles within one zone was calculated and then thresholded by a prediction probability of $50 \%$ for the class land ice. In case of multi-coverage by several satellite scenes, more robust results were obtained by merging the prediction probabilities. Morphological filtering and the exclusion of higher ice sheet areas by integrating elevation information from the TanDEM-X Polar DEM 90 (Wessel et al., 2021) reduced further errors. Finally, from the binary segmentation results, the border between both classes was extracted as the final coastline.

\subsection{Derivation of calving front change}

Calving front change was estimated by calculating the change in area between the coastlines in 1997, 2009, and 2018 over the area of floating glacier tongues and ice shelves excluding grounded glacier termini. As coastline extraction and delineation are very subjective tasks, and all coastlines originated from different sources and resolutions, deviations occurred in many areas. Areas of fast ice, mélange, and icebergs trapped in sea ice were error sources. For the automatically extracted 2018 coastline, errors existed along the western Antarctic Peninsula and in areas where only single-pol imagery was available. The MODIS-derived coastline often included snow-covered sea ice, which is difficult to distinguish from glacier ice in optical imagery. To minimize errors and mismatches, all three coastlines were manually corrected and adjusted. Each coastline product was corrected based on the satellite imagery from which they were originally created. After manual correction any change in area between the coastline products could be attributed to glacier front change. From each coastline a raster (resolution $40 \times 40 \mathrm{~m}$ ) was created with a unique value over the ice-covered area. All three raster layers were stacked and summed up, so each raster value pixel is associated with retreat or advance of the specific year. The area change was calculated for each major floating ice shelf and glacier tongue wider than $3 \mathrm{~km}$ based on a $40 \mathrm{~m}$ resolution raster in polar stereographic projection. To account for inaccuracies in the manual adjustment of all coastlines, we measured the accuracy as the area change over 30 randomly picked stable coastline areas. Any change over those regions can be attributed to errors in manual delineation, imagery resolution differences, and errors in orthorectification of the different satellite image mosaics. The error is calculated per kilometer of the coastline and calculated in proportion to the measured front length. On average, the coastlines deviated \pm 1.2 pixels per kilometer per year. Broken down for each coastline product, the error between 1997-2009 was 0.4 pixels per kilometer per year, 2.3 pixels per kilometer per year between 2009-2018, and 0.9 pixels per kilometer per year between 1997-2018. 
Table 1. Summary of processed climate variable data sets.

\begin{tabular}{|c|c|c|c|c|c|c|}
\hline $\begin{array}{l}\text { Climate } \\
\text { variable }\end{array}$ & $\begin{array}{l}\text { Time } \\
\text { span }\end{array}$ & Season & $\begin{array}{l}\text { Spatial } \\
\text { resolution }\end{array}$ & Accuracy & Data & $\begin{array}{l}\text { Data } \\
\text { store }\end{array}$ \\
\hline Air temperature & $1982-2018$ & $\begin{array}{l}\text { Summer (October-March) } \\
\text { Winter (April-September) }\end{array}$ & $9 \mathrm{~km}$ & $0.13-2.0^{\circ} \mathrm{C}$ & Modeled & CDS \\
\hline Snowmelt & 1982-2018 & December-February & $9 \mathrm{~km}$ & - & Modeled & CDS \\
\hline Zonal wind & 1982-2018 & December-February & $31 \mathrm{~km}$ & $2.8 \mathrm{~m} / \mathrm{s}$ & Modeled & $\mathrm{CDS}$ \\
\hline Sea ice days & $\begin{array}{l}1982-2018 \\
\text { (not 1986) }\end{array}$ & April-October & $25 \mathrm{~km}$ & $\begin{array}{l}8 \% \text { standard devi- } \\
\text { ation compared to } \\
\text { ice chart }\end{array}$ & Modeled + satellite & Osisaf \\
\hline Sea surface temperature & $1982-2018$ & October-March & $\sim 5.5 \mathrm{~km}$ & -0.1 to $-0.4^{\circ} \mathrm{C}$ & Multiple satellites & CDS \\
\hline
\end{tabular}

\subsection{Climate data correlation}

In order to assess the influence of climate variables (such as air temperature, sea ice days, sea surface temperature, snowmelt, and zonal wind) on glacier and ice shelf retreat, we spatially correlated the percentage of advance and retreat for each minor glacier basin (as defined by Mouginot, 2017) with the decadal mean value of each climate variable. Means were calculated from 37 years of climate data for the three time periods 1982-1996, 1997-2008, and 2009-2018. The first period is used as the reference period to measure temporal changes in the following two decades. Hence, the inputs of the correlation covered the two time spans 19972008 and 2009-2018 for which also the glacier retreat was calculated. To also assess relative changes in the variables at previous times, we subtracted the reference mean (19821996). This means the relative values indicate the change in an environmental variable within the first and second decade compared to the reference time frame. Zonal wind, sea ice coverage, and sea surface temperature means were calculated within a $100 \mathrm{~km}$ seawards buffer along the coastline. Mean air temperature and snowmelt were calculated within a $100 \mathrm{~km}$ buffer landwards from the coastline, covering the surface of ice shelves. The $100 \mathrm{~km}$ landwards buffer was chosen as the best trade-off to calculate averages over the ice shelf area by not including too much of the ice sheet. Due to a circum-Antarctic analysis, this is only a rough approximation, and especially over smaller glaciers within steep terrain, the average includes changes not only over the glacier tongue but also the surrounding area. Again, relative values were calculated by subtracting the reference mean 1982-1996. To remove the effect of different basin sizes and different amounts of ice discharge, we took the percentage of advance and retreat within each basin instead of the absolute value for the correlation. Input data for the Pearson correlation were the mean of all assessed climate variables (absolute and relative averages) as well as the percentage of retreat and advance. This created 14 different variables, which were correlated with each other based on 188 observations $(N=188)$. The number of observations is derived from 94 assessed glacier basins with variable averages for the two different decades (1997-2008 and 2009-2018).

\section{Results}

\subsection{Advance and retreat of Antarctic glaciers and ice shelves}

Circum-Antarctic glacier and ice shelf front changes were assessed by comparing Antarctic coastline products during 1997-2008 and 2009-2018. The results are shown in Fig. 2. Between 1997 and 2008 ice shelf and glacier extents decreased by $-29618 \pm 1193 \mathrm{~km}^{2}$, where $69 \%$ of the total changed area retreated, and $31 \%$ advanced (see Table 2 for all change rates). In contrast, during the period 2009 to 2018 a slight area increase of $7108 \pm 1029 \mathrm{~km}^{2}$ could be observed, with $44 \%$ of the total changed area retreating and $56 \%$ advancing. The locations of area change are almost similar for both observation periods. Ice shelves along the Antarctic Peninsula retreated over the entire observation period (19972018). The only exception was the advance of the Larsen D Ice Shelf, which is located close to the Ronne Ice Shelf in the Weddell Sea (see Fig. 2). Between 1997 and 2008, the large disintegration events of the Larsen B, Wilkins, and Wordie ice shelves resulted in a $37 \%$ higher calving amount from the Antarctic Peninsula as compared to the amount calved from this region between 2009-2018. During the second decade the breakup of iceberg A- 68 from the Larsen C Ice Shelf and the further disintegration of the Wilkins Ice Shelf were regions of strong area loss. In total, the rate of retreat along the Antarctic Peninsula was 5-6 times higher than glacier advance in this region over the last 20 years.

West Antarctica lost more than 3 times as much calving area in the first decade (1997-2008) compared to 2009-2018. In West Antarctica, $75 \%$ of glacier and ice shelf retreat can be attributed to the calving of Ronne and Ross West ice shelves during the first decade. The retreat at WAIS was significantly lower in the second decade, whereas the Ross and Ronne ice shelves started to advance again. Excluding these 
two ice shelves, the rest of West Antarctica experienced predominant glacier and ice shelf retreat during both observation periods as shown in Fig. 2. Pine Island and Thwaites glaciers retreated over the entire observation period (19972018). The Getz and Abbot ice shelves had stable front positions in the first decade but started to retreat after 2008. Only the Crosson Ice Shelf showed a contradicting pattern, with retreat in the first and re-advance in the second decade.

The glaciers and ice shelves of the EAIS showed an overall stable advancing tendency with similar rates for both decades, with $2638 \pm 418 \mathrm{~km}^{2}$ more retreat during the first (attributed to calving of Ross East Ice Shelf) and no clear change in advance $\left(104 \pm 872 \mathrm{~km}^{2}\right)$ during the second decade. The strongest advance was observed for the Amery and Filchner ice shelves as well as at the shelves of Dronning Maud Land and Queen Mary Land (see Fig. 1 for location). During 1997-2008, clear retreat appeared for the Ross East Ice Shelf and along Enderby Land, especially in Shirase Bay. Wilkes Land and Victoria Land shared equal proportional amounts of retreat and advance. Between 2009 and 2018, the Ross Ice Shelf and Enderby Land entered a phase of advance whereas Wilkes Land, George V Land, and Adélie Land started to retreat predominately.

\subsection{Air temperature}

The mean Antarctic air temperature was equal for both decades during winter but in summer $+0.6^{\circ} \mathrm{C}$ higher in the second decade (2009-2018). However, the overall mean does not reflect the strong regional differences in air temperature changes as shown in Fig. 3. During summer and winter the Antarctic Peninsula and the adjoining coast along the Bellingshausen and Amundsen sea sectors as well as Queen Mary Land (EAIS) were cooler between 2009-2018, whereas the interior of the ice sheet warmed during this period. Compared to the reference mean (1982-1996) summer temperatures between 1997-2008 were cooler except for the Peninsula, Queen Mary Land, and the Ross West and Filchner ice shelves. In the second decade this changed in sign where the Antarctic Peninsula started to cool down and the interior increased in temperature. For the winter months almost over the entire Antarctica continent a warming tendency was observed compared to the reference mean. The only exceptions were Victoria Land, Oates Land, and George V Land (all EAIS). Additionally, over the Getz Ice Shelf (WAIS) cooler temperatures by $1{ }^{\circ} \mathrm{C}$ occurred in 2009-2018 compared to the reference mean. For Dronning Maud Land (EAIS) a strong change was observed as the ice shelf surfaces warmed up to $1.8^{\circ} \mathrm{C}$ in the second decade.

\subsection{Sea ice days}

Changes in sea ice days are shown in Fig. 4, and absolute numbers for sea ice days are provided in the Supplement in Fig. S1. A decrease or increase in sea ice days refers to the difference in the number of sea ice days per year (during the sea ice season April-October) compared to the reference mean. The strongest decrease in sea ice days could be observed at the northern tip of the Antarctic Peninsula, with a shorter sea ice cover per year by up to $40 \mathrm{~d}$ during the first decade compared to the reference mean. During 1997 and 2008 a decrease in sea ice days was observed along the Bellingshausen Sea Sector, with up to $20 \mathrm{~d}$ less, and in the Amundsen Sea Sector, with up to 5-10 d less. Compared to the first decade, the mean sea ice cover persisted longer in the second decade along the Antarctic Peninsula and the Bellingshausen Sea Sector, whereas in the Amundsen Sea Sector the sea ice days decreased by up to $10 \mathrm{~d}$ less compared to the first decade. Along East Antarctica, sea ice coverage increased $10 \mathrm{~d}$ on average except for Dronning Maud Land, with a slight decrease of up to $5 \mathrm{~d}$. When comparing the two decades more sea ice days occurred during 2009 to 2018 along East Antarctica and the northernmost Antarctic Peninsula, whereas the decrease along West Antarctica continues. Changes in sea ice days were less extreme along East Antarctica, with $\pm 10 \mathrm{~d}$ in difference compared to 1982-1996. Between 1997-2008 the duration of sea ice cover was up to $5 \mathrm{~d}$ shorter along Dronning Maud Land and Wilkes Land compared to the reference mean. In the second decade sea ice days along all of East Antarctica increased, with the highest increase along Wilkes Land, by up to $10 \mathrm{~d}$ (compared to 1982-1996).

\subsection{Sea surface temperature}

The changes in sea surface temperature during months with little sea ice cover (October-March) relative to the reference mean are shown in Fig. 5 (absolute values in Fig. S2). Sea surface temperatures of the Southern Ocean cooled $\left(\sim-0.5^{\circ} \mathrm{C}\right)$ along East Antarctica and warmed along West Antarctica and the western Antarctic Peninsula $\left(\sim+0.5^{\circ} \mathrm{C}\right)$ within the last two decades compared to 1982-1996, which is above the data uncertainty of 0.1 to $0.4^{\circ} \mathrm{C}$. The warming was less strong in the first decade and intensified within the second decade, especially in the Bellingshausen Sea Sector, with maxima at George VI north $\left(+0.65^{\circ} \mathrm{C}\right)$ and Pine Island Bay $\left(+0.35^{\circ} \mathrm{C}\right)$ and with a slightly weaker increase along the Amundsen Sea Sector $\left(+0.15^{\circ} \mathrm{C}\right)$. The cooling along the East Antarctic was less strong in the second decade. Along East Antarctica for Amery Ice Shelf $\left(+0.35^{\circ} \mathrm{C}\right)$, West Ice Shelf $\left(+0.2^{\circ} \mathrm{C}\right)$, and Shackleton Ice Shelf $\left(+0.25^{\circ} \mathrm{C}\right)$ warming was observed compared to the first decade.

\subsection{Snowmelt}

Snowmelt over the Antarctic Peninsula (see Fig. 6) was more extensive during the reference mean compared to the recent two decades. This is the reason why relative snowmelt in 1997-2008 and 2009-2018 was mostly negative, with up to $-0.3 \mathrm{~mm}$ w.e. per day. Nevertheless, strong snowmelt also 
Table 2. Retreat and advance rates of Antarctic glaciers and ice shelves for each basin between 1997 and 2018 (upper table). Total lost and gained ice shelf or glacier area per decade (lower table). For basin abbreviations see Fig. 2.

\begin{tabular}{|c|c|c|c|c|c|c|c|}
\hline & \multirow[b]{2}{*}{ Basin } & \multicolumn{2}{|c|}{ 1997-2008 } & \multicolumn{2}{|c|}{ 2009-2018 } & \multicolumn{2}{|c|}{ 1997-2018 } \\
\hline & & Advance $\left(\mathrm{km}^{2} / \mathrm{yr}\right)$ & Retreat $\left(\mathrm{km}^{2} / \mathrm{yr}\right)$ & Advance $\left(\mathrm{km}^{2} / \mathrm{yr}\right)$ & Retreat $\left(\mathrm{km}^{2} / \mathrm{yr}\right)$ & Advance $\left(\mathrm{km}^{2} / \mathrm{yr}\right)$ & Retreat $\left(\mathrm{km}^{2} / \mathrm{yr}\right)$ \\
\hline \multirow[t]{11}{*}{ EAIS } & A-Ap & $249 \pm 14.9$ & $164 \pm 17.4$ & $295 \pm 27.5$ & $112 \pm 13$ & $215 \pm 11.8$ & $85 \pm 6.5$ \\
\hline & Ap-B & $62 \pm 4.8$ & $89 \pm 5.6$ & $80 \pm 8.9$ & $53 \pm 4.2$ & $34 \pm 3.8$ & $36 \pm 2.1$ \\
\hline & $\mathrm{B}-\mathrm{C}$ & $187 \pm 1.9$ & $4 \pm 2.2$ & $186 \pm 3.5$ & $20 \pm 1.6$ & $179 \pm 1.5$ & $4 \pm 0.8$ \\
\hline & C-Cp & $380 \pm 7.7$ & $167 \pm 9$ & $363 \pm 14.2$ & $153 \pm 6.7$ & $323 \pm 6.1$ & $111 \pm 3.3$ \\
\hline & Cp-D & $49 \pm 4.6$ & $58 \pm 5.4$ & $45 \pm 8.6$ & $97 \pm 4.1$ & $23 \pm 3.7$ & $51 \pm 2$ \\
\hline & D-Dp & $154 \pm 5$ & $64 \pm 5.8$ & $156 \pm 9.2$ & $317 \pm 4.3$ & $85 \pm 3.9$ & $111 \pm 2.2$ \\
\hline & Dp-E & $68 \pm 9.5$ & $58 \pm 11.1$ & $74 \pm 17.5$ & $81 \pm 8.3$ & $34 \pm 7.5$ & $32 \pm 4.1$ \\
\hline & E-Ep & $6 \pm 3$ & $411 \pm 3.5$ & $156 \pm 5.5$ & $8 \pm 2.6$ & $5 \pm 2.4$ & $154 \pm 1.3$ \\
\hline & Jpp-K & $163 \pm 2.1$ & $2 \pm 2.4$ & $252 \pm 3.8$ & $2 \pm 1.8$ & $203 \pm 1.6$ & $1 \pm 0.9$ \\
\hline & K-A & $306 \pm 7.8$ & $23 \pm 9.1$ & $285 \pm 14.3$ & $82 \pm 6.8$ & $270 \pm 6.2$ & $24 \pm 3.4$ \\
\hline & EAIS & $1626 \pm 61.1$ & $1040 \pm 71.4$ & $1894 \pm 112.9$ & $926 \pm 53.4$ & $1370 \pm 48.6$ & $607 \pm 26.6$ \\
\hline \multirow[t]{4}{*}{ AP } & Hp-I & $20 \pm 4.5$ & $328 \pm 5.3$ & $25 \pm 8.4$ & $305 \pm 4$ & $11 \pm 3.6$ & $306 \pm 2$ \\
\hline & I-Ipp & $87 \pm 3.9$ & $938 \pm 4.6$ & $59 \pm 7.2$ & $592 \pm 3.4$ & $12 \pm 3.1$ & $715 \pm 1.7$ \\
\hline & Ipp-J & $91 \pm 4.5$ & $67 \pm 5.3$ & $118 \pm 8.4$ & $75 \pm 4$ & $71 \pm 3.6$ & $38 \pm 2$ \\
\hline & $\mathrm{AP}$ & $198 \pm 13$ & $1333 \pm 15.2$ & $202 \pm 24$ & $972 \pm 11.4$ & $94 \pm 10.3$ & $1060 \pm 5.7$ \\
\hline \multirow[t]{8}{*}{ WAIS } & Ep-F & $160 \pm 7.7$ & $868 \pm 8.9$ & $452 \pm 14.1$ & $74 \pm 6.7$ & $136 \pm 6.1$ & $341 \pm 3.3$ \\
\hline & F-G & $103 \pm 5.2$ & $101 \pm 6.1$ & $73 \pm 9.7$ & $106 \pm 4.6$ & $59 \pm 4.2$ & $73 \pm 2.3$ \\
\hline & G-H & $40 \pm 3.6$ & $371 \pm 4.2$ & $49 \pm 6.7$ & $369 \pm 3.2$ & $14 \pm 2.9$ & $340 \pm 1.6$ \\
\hline & $\mathrm{H}-\mathrm{Hp}$ & $26 \pm 3.7$ & $35 \pm 4.3$ & $6 \pm 6.8$ & $97 \pm 3.2$ & $3 \pm 2.9$ & $51 \pm 1.6$ \\
\hline & J-Jpp & $29 \pm 5.8$ & $1127 \pm 6.8$ & $643 \pm 10.7$ & $26 \pm 5.1$ & $13 \pm 4.6$ & $317 \pm 2.5$ \\
\hline & WAIS & $358 \pm 26$ & $2502 \pm 30.4$ & $1222 \pm 48$ & $672 \pm 22.7$ & $225 \pm 20.7$ & $1121 \pm 11.3$ \\
\hline & & \multicolumn{2}{|c|}{ 1997-2008 } & \multicolumn{2}{|c|}{ 2009-2018 } & \multicolumn{2}{|c|}{$1997-2018$} \\
\hline & Region & Advance $\left(\mathrm{km}^{2}\right)$ & Retreat $\left(\mathrm{km}^{2}\right)$ & Advance $\left(\mathrm{km}^{2}\right)$ & Retreat $\left(\mathrm{km}^{2}\right)$ & Advance $\left(\mathrm{km}^{2}\right)$ & Retreat $\left(\mathrm{km}^{2}\right)$ \\
\hline WAIS & & $3942 \pm 286$ & $27525 \pm 334$ & $11612 \pm 456$ & $6382 \pm 216$ & $4617 \pm 424$ & $22970 \pm 232$ \\
\hline AP & & $2178 \pm 143$ & $14660 \pm 167$ & $1920 \pm 228$ & $9232 \pm 36$ & $1929 \pm 212$ & $21722 \pm 116$ \\
\hline EAIS & & $17886 \pm 672$ & $11439 \pm 785$ & $17990 \pm 1072$ & $8801 \pm 51$ & $28089 \pm 997$ & $12453 \pm 545$ \\
\hline AIS & & $24006 \pm 1100$ & $53624 \pm 1286$ & $31522 \pm 1756$ & $24414 \pm 303$ & $34636 \pm 1632$ & $57146 \pm 893$ \\
\hline \multicolumn{2}{|c|}{ Difference } & \multicolumn{2}{|c|}{$-29618 \pm 1193$} & \multicolumn{2}{|c|}{$7108 \pm 1029$} & \multicolumn{2}{|c|}{$-22510 \pm 1263$} \\
\hline
\end{tabular}

occurred during the recent two decades but predominantly over the Wilkins and Larsen B ice shelves as well as at the northern tip of the Antarctic Peninsula. During the reference mean, snowmelt was greatest on the Antarctic Peninsula, Ronne, Abbot, Shackleton, and Amery ice shelves as well as Shirase Bay. In the first decade snowmelt expanded to Pine Island Bay, the Getz and Ross ice shelves as well as along Wilkes Land, George V Land, and Dronning Maud Land in East Antarctica. In all cases, the increase in melt was small with $0.1 \mathrm{~mm}$ w.e. per day. Within the most recent decade melt became more extensive $(+0.1 \mathrm{~mm}$ w.e. per day) over George V Land, Oates Land, and parts of Wilkes Land as well as over Getz and Sulzberger ice shelves. Smaller areas of strong surface melt in Pine Island Bay and Dronning Maud Land were only observed during the first decade.

\subsection{Zonal wind}

Figure 7 shows changes in zonal wind around the Antarctic continent (absolute values in Fig. S3). In the first decade, weakening easterlies $(\sim+0.5 \mathrm{~m} / \mathrm{s})$ were observed along the Antarctic Peninsula and the Bellingshausen and Amundsen sea sectors as well as in East Antarctica in the area of Shackleton Ice Shelf. Stronger easterlies occurred only at George V Land and Dronning Maud Land (both EAIS). Within the second decade the strengthening westerlies along East Antarctica expanded from Amery Ice Shelf to Victoria Land, with up to $+1 \mathrm{~m} / \mathrm{s}$. Additionally, the westerlies strengthened in the Bellingshausen Sea Sector but weakened in the Amundsen Sea Sector. Strong dominating easterlies occurred along Dronning Maud Land, with up to $-0.75 \mathrm{~m} / \mathrm{s}$ within the second decade. 


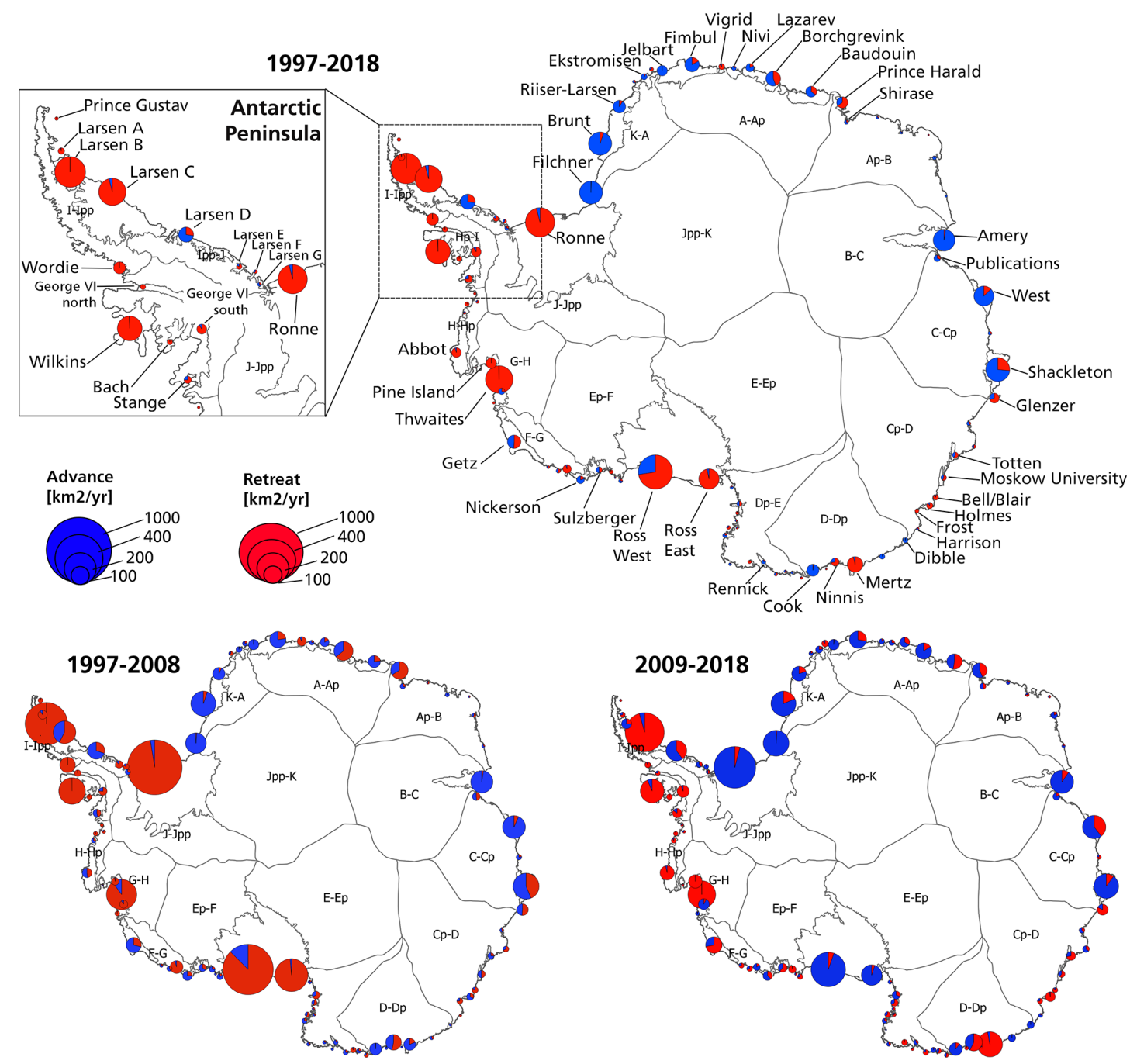

Figure 2. Glacier and ice shelf extent changes for major glaciers and ice shelves over the last two decades. Circles indicate the rate of retreat or advance. Major ice sheet basins as defined by Rignot et al. (2011).

\subsection{Southern Annular Mode (SAM)}

Changes in zonal wind direction are closely connected to fluctuations in SAM. Positive phases of SAM weaken the easterlies around the Antarctic continent and shift the westerlies poleward closer to the coastline. Phases of a positive SAM occur when air pressure over the Antarctic Ice Sheet lowers but rises over the subtropical ocean. Figure 8 shows the evolution of the SAM index since 1960 based on calculations from Marshall (2003). The 5-year moving average (in red) of the SAM has been positive since 1992, with positive values during the first and second decade. Annual peak events with exceptionally high SAM occurred in 1997/1998 and 2014/2015 (shown in blue - annual - and orange summer only). Note the shift in peaks as the summer value for SAM averages values from December to February (December indicates the year).

\subsection{Correlation between climate variables and calving front position}

Potential drivers of calving front retreat were diagnosed by correlating the analyzed climate variables with the percentage of retreat or advance within each glacier or ice shelf basin. This allows for the assessment of a potential spatial relationship between calving front retreat and changes in environmental variables. The results of the Pearson correlation are displayed in Fig. 9. Dark-blue colors indicate a strong positive and dark-red colors a strong negative correlation. Stars indicate a significant Pearson correlation, with stars for $p=0.05\left(^{*}\right), 0.01\left(^{* *}\right)$, and $0.001\left(^{* * *}\right)$. Correlations for retreat and advance are counterparts; hence correlations are of the same magnitude for each climate variable but with reversed sign. Overall, weak to moderate correlations with significance occur for relative summer sea surface temperature, absolute air temperature, snowmelt, rela- 


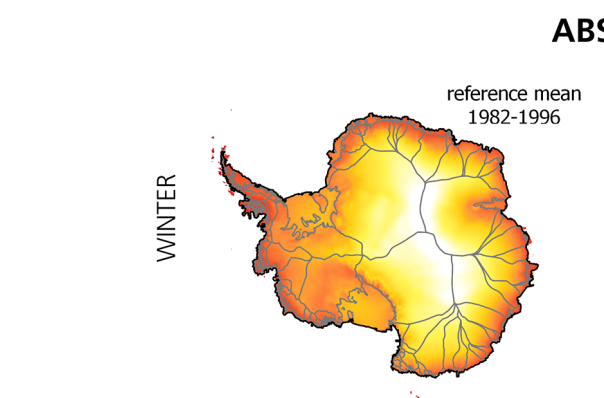

ABSOLUTE

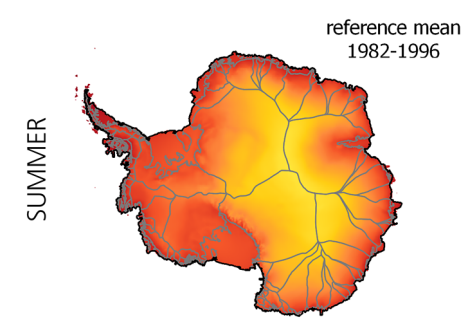

Mean

Air Temperature

in ${ }^{\circ} \mathrm{C}$

$<-60$

$-50$

$-40$

$-30$

$-20$

$-10$

RELATIVE
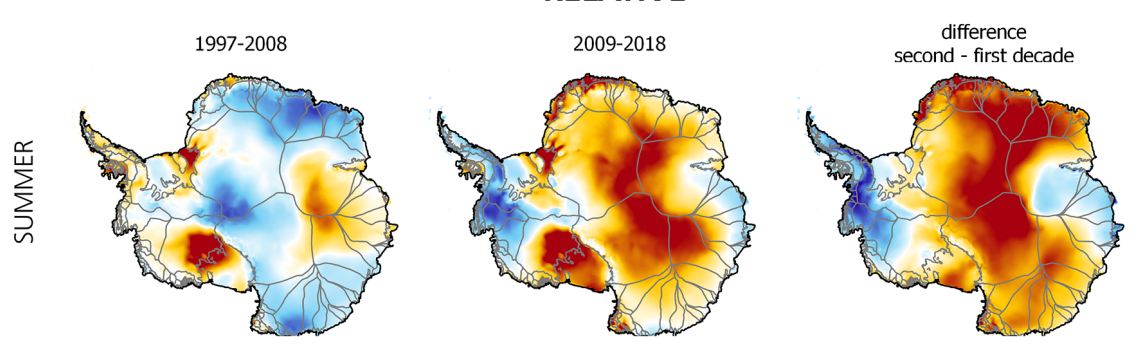

Air Temperature

Difference in ${ }^{\circ} \mathrm{C}$
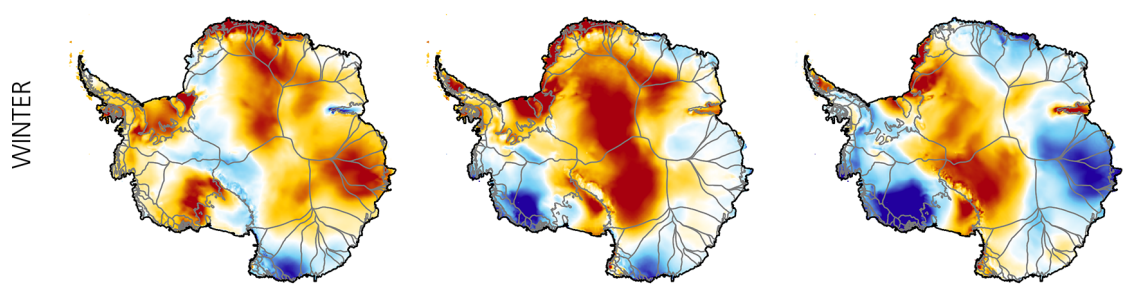

$\square<-1$

$-0.5$

0

0.5

$>1$

Figure 3. Absolute air temperature for the reference mean measured between 1982 and 1996 and relative changes compared to the reference mean. Additionally, the difference between the first and second decade is illustrated.
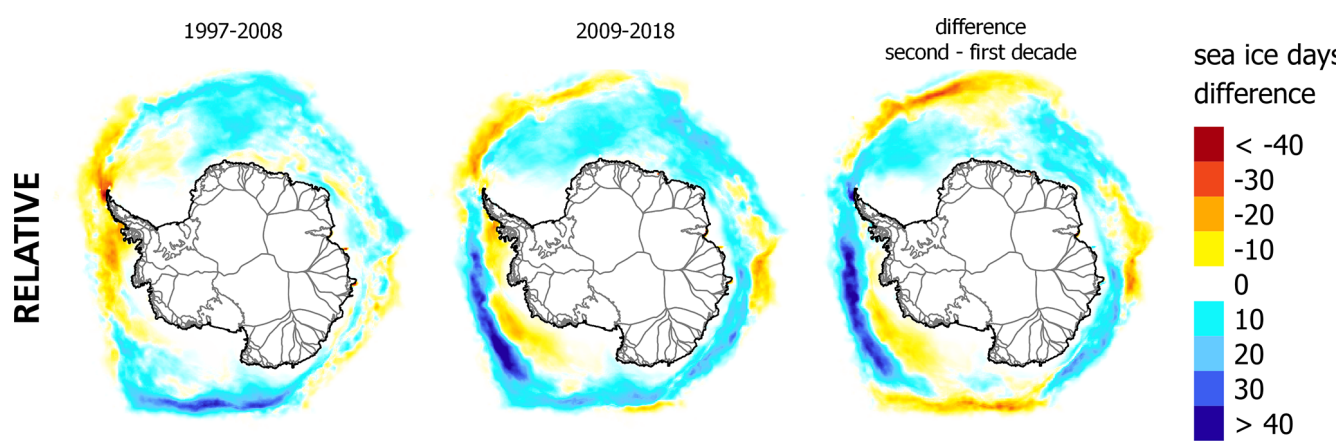

Figure 4. Difference in the number of sea ice days per year (during the sea ice season from April to October) compared to the reference mean (1982-1996) and the difference in sea ice cover duration between both decades.

tive zonal wind speed, and sea ice days. The strongest positive linear relationship $(r=0.44)$ exists between calving front retreat and relative sea surface temperature. Slightly weaker is the positive correlation between glacier and ice shelf front retreat and absolute air temperature on the ice shelf surface ( $r=0.18$ for summer, $r=0.23$ for winter). A relatively more positive zonal wind (hence strengthening westerlies) correlates positively with calving front retreat $(r=0.30)$, but the absolute strength of zonal winds does not. Decreases in sea ice days correlate positively with calving front retreat ( $r=0.33$ (absolute), $r=0.27$ (relative)). The mean daily amount of snowmelt correlates weakly but significantly with glacier and ice shelf front retreat $(r=0.17)$. The correlation of the climate variables among each other reflects that they are closely linked to each other. Higher air ( $r=-0.26$ for summer, $r=-0.36$ for winter) and sea surface temperatures $(r=0.44)$ have a negative relationship to an increase in sea ice days. An increase in sea ice days negatively correlated with an increase in zonal winds $(r=0.31)$. Stronger snowmelt correlates positively with warmer sum- 

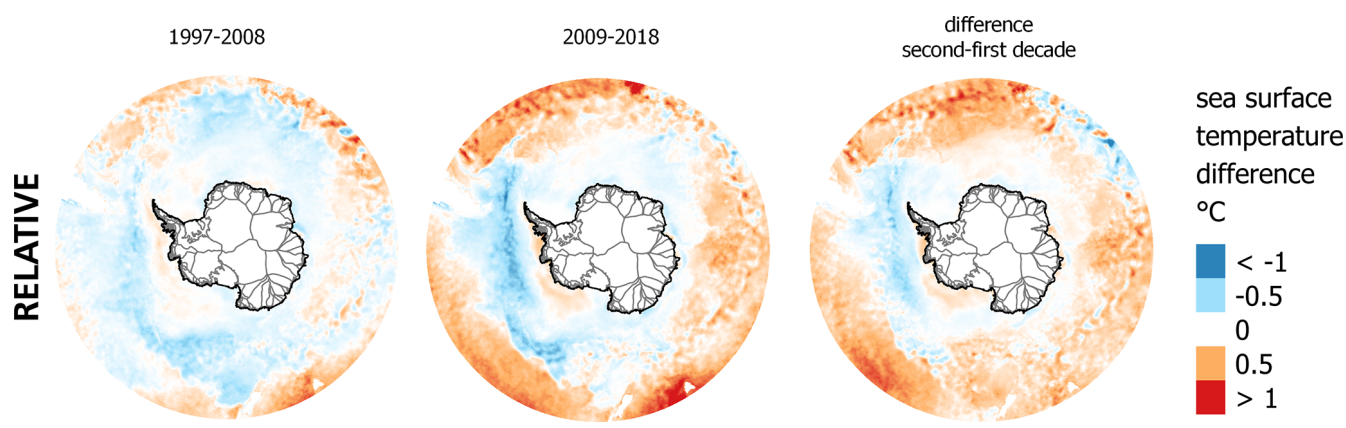

Figure 5. Mean sea surface temperature changes (October-March) compared to 1982-1996 and the difference in sea surface temperatures between both decades.
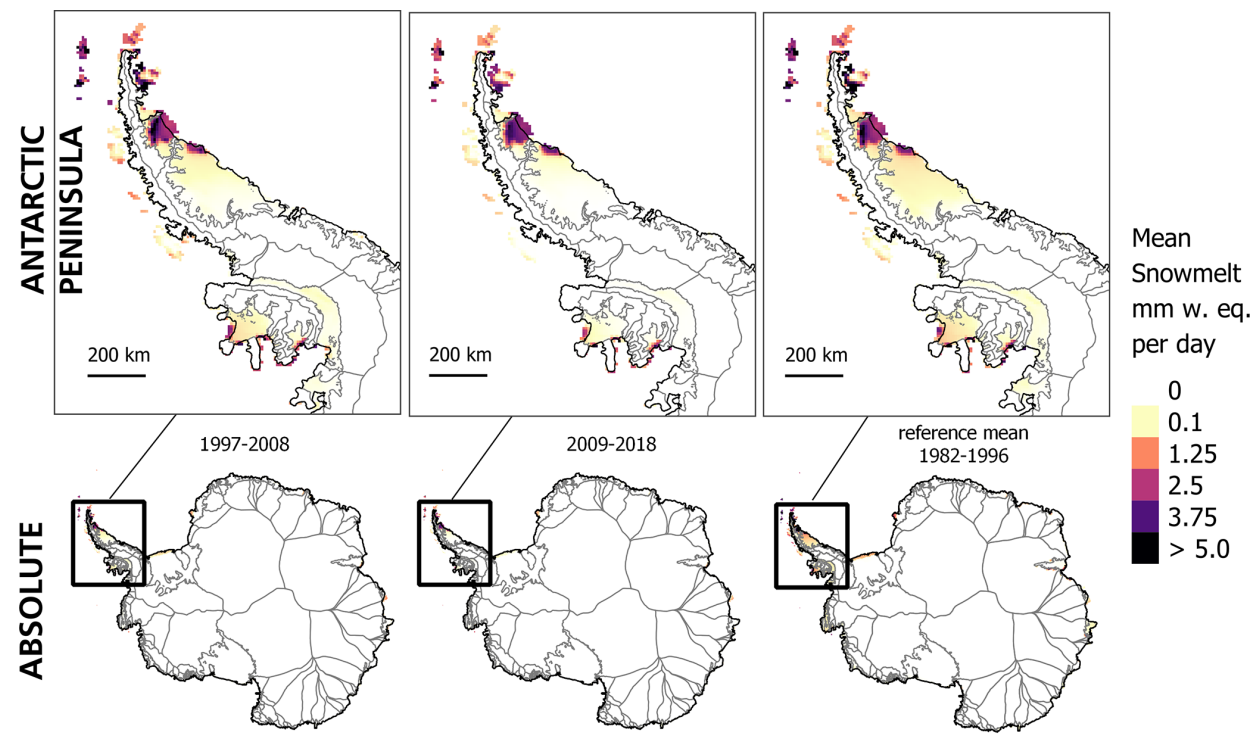

1.25

2.5
3.75

$>5.0$
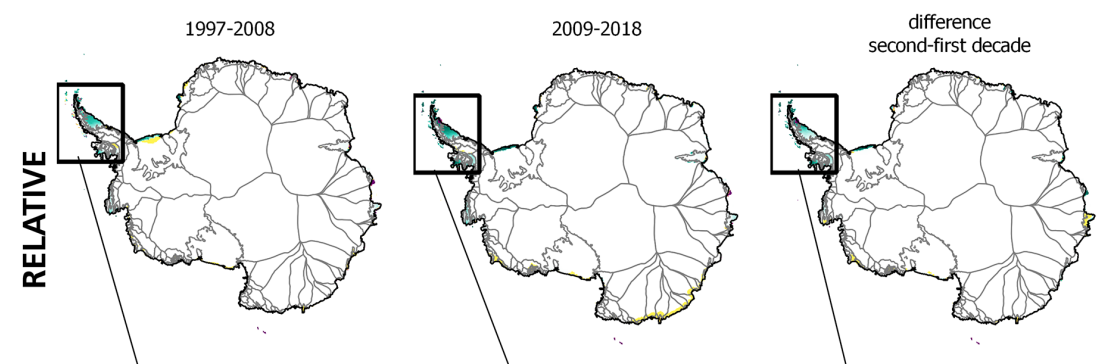

Difference

in mean

snowmelt

$\mathrm{mm}$ w. eq.

per day
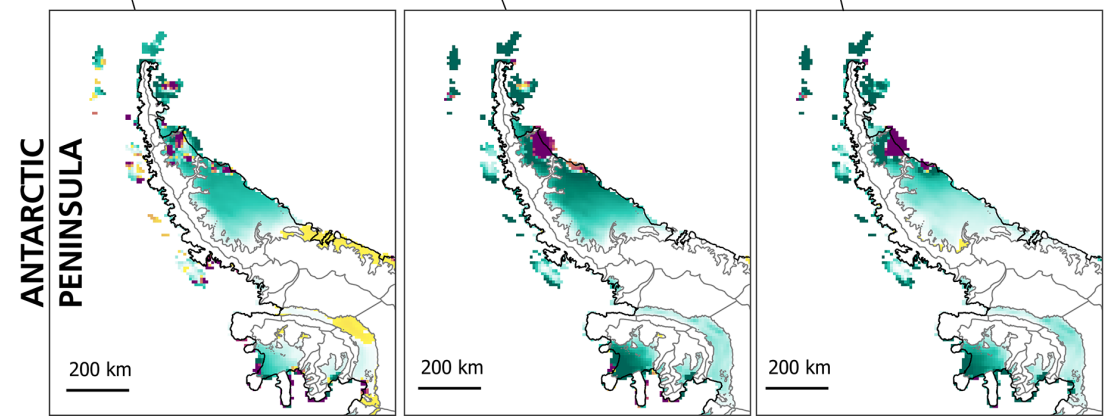

$<-0.3$

$-0.2$

$-0.1$

0

0.1

0.2

$>0.3$

Figure 6. Mean snowmelt over Antarctica with enlarged views of the Antarctic Peninsula. Snowmelt is given in millimeters of water equivalent per day. The mean snowmelt was calculated over $90 \mathrm{~d}$ per year during the summer months of December to February. 

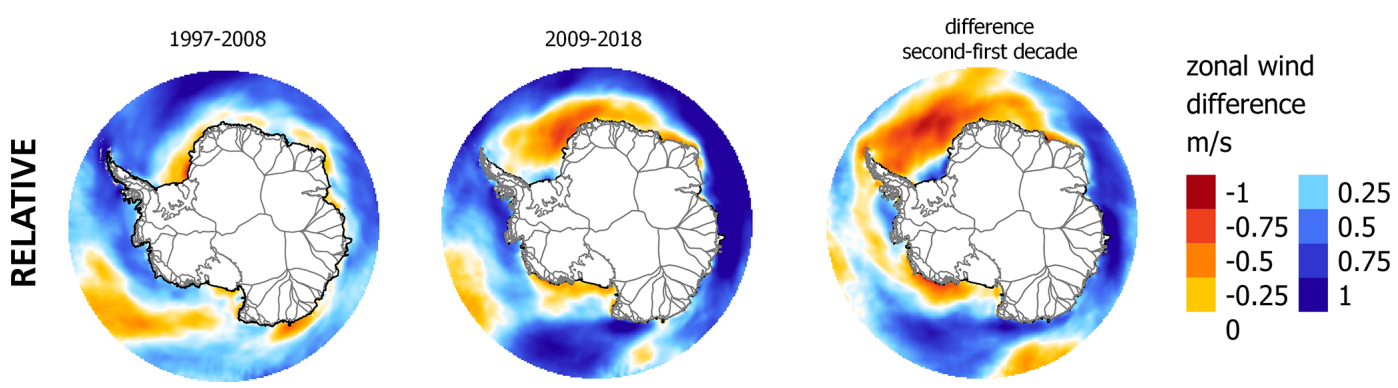

Figure 7. Zonal wind (west to east) around the Antarctic continent in m/s for 1997-2008 and 2009-2018 compared to the reference mean. Additionally, the difference in wind speed between both decades is illustrated. Positive shifts in zonal wind indicate stronger westerlies with the potential to cause upwelling of warm Circumpolar Deep Water.

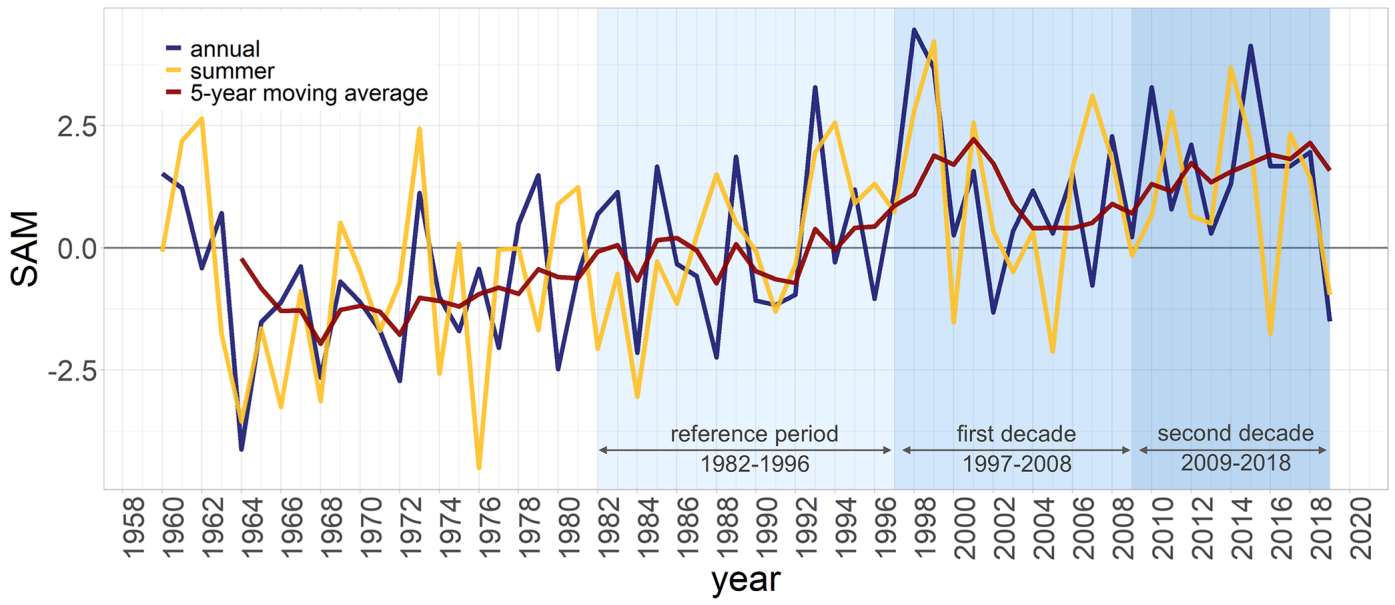

Figure 8. Southern Annular Mode (SAM) since 1960. Values are given for the annual SAM (blue), SAM during summer (orange), and a 5-year moving average for the annual SAM (red). The blue background indicates the investigated periods as delimited by the available coastline and climate data. For SAM during summer (December-February), the beginning of austral summer (hence December) indicates the year of the peak. Data: Marshall (2018).

mer $(r=0.46)$ and winter $(r=0.37)$ air temperatures. An increase in zonal winds was positively related to decreasing summer air temperatures ( $r=-0.31$ for summer).

\section{Discussion}

For the first time, this study presents circum-Antarctic glacier and ice shelf front change over two decades. The correlation analysis indicates that a spatial relationship exists between calving front retreat and strengthening westerlies, higher air temperatures, intense snowmelt, decreasing sea ice cover, and rising sea surface temperature. We want to discuss whether these external environmental factors were responsible for the observed glacier retreat or if internal glaciological forces were the key driver instead. To address this question, two major challenges arise. First, a significant correlation between calving front retreat or advance and climate variables cannot alone provide conclusive evidence of a causal link. Second, the retreat forced by environmental drivers has to be disentangled from retreat caused by internal glaciological and external mechanical factors. To find solid evidence for drivers of glacier and ice shelf retreat, we discuss observed glacier and ice shelf retreat on the basis of findings from previous studies in combination with measured changes in analyzed climate variables.

\subsection{Antarctic Peninsula}

Along the Antarctic Peninsula a decrease in ice shelf extent resulted mainly from the disintegration and retreat of Larsen B, Larsen C, Wilkins, and Wordie ice shelves (see Fig. 2). The Wordie Ice Shelf disintegrated in a series of calving events beginning in the 1960s, which were controlled by several pinning points (Friedl et al., 2018). The initial destabilization of the ice shelf was likely caused by a shift in flow, which caused rift development at the ice rises and a collapse in 1989 (Walker and Gardner, 2017). Additional destabilization occurred through basal-melt-induced thinning (Depoorter et al., 2013; Friedl et al., 2018; Rignot et al., 2013; Walker and Gardner, 2017). A later calving event accompa- 


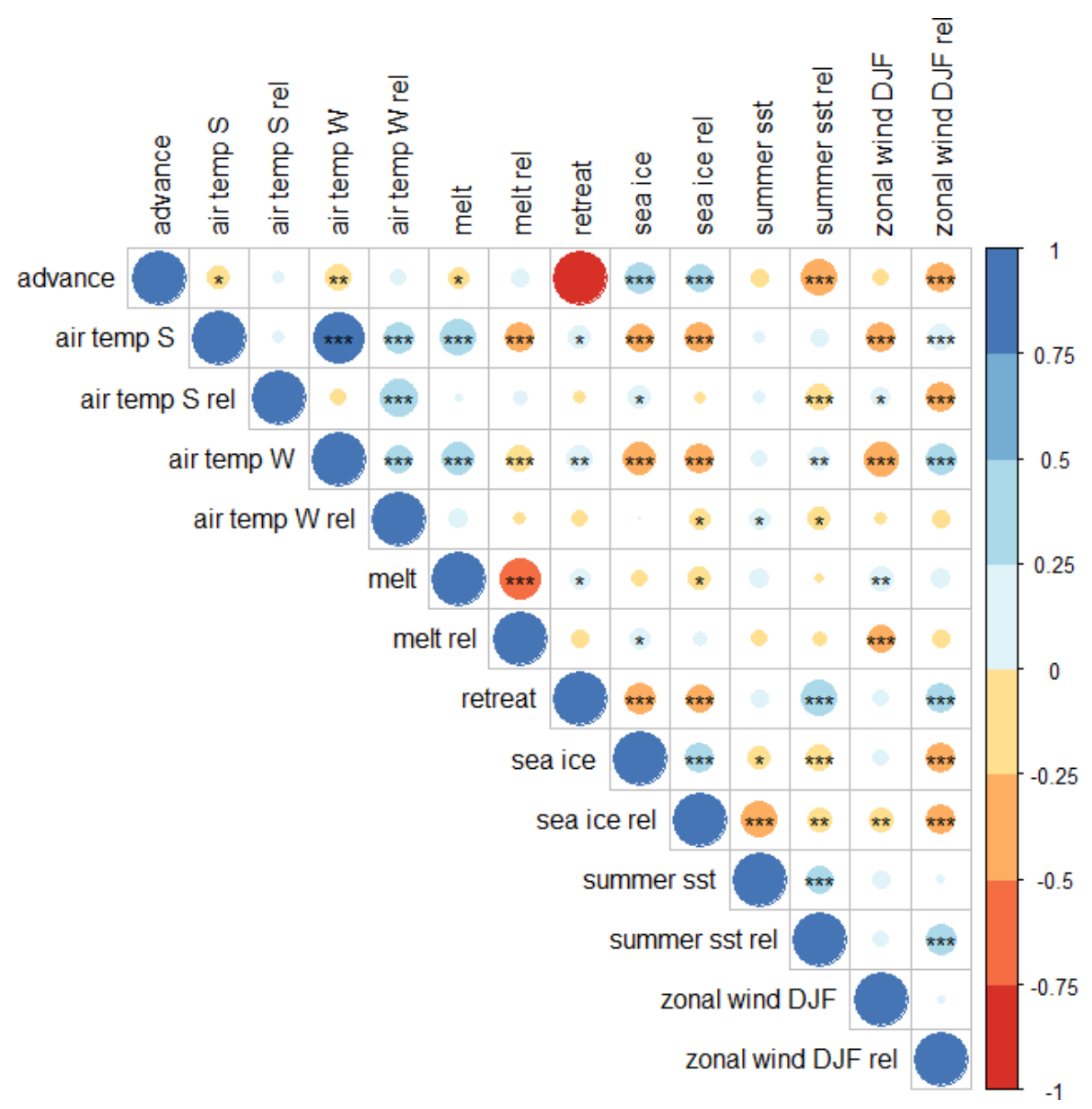

Figure 9. Correlation between glacier and ice shelf change and the analyzed climate variables winter and summer air temperature, snowmelt, sea ice days, summer sea surface temperatures, and zonal wind speed. Color and circle size indicate the correlation coefficient. Stars indicate significance levels for $p=0.05\left(^{*}\right), 0.01\left({ }^{* *}\right)$, and $0.001\left(^{* * *}\right)$. S: summer; W: winter; rel: relative to 1982-1996; DJF: December-February.

nied by thinning and acceleration was associated with upwelling of warm CDW, which was strong in the years 2008 to 2011 due to consecutive years of positive SAM (Walker and Gardner, 2017), with a peak in 2010 (SAM index above 2.5; see Fig. 8). In addition to the continuous thinning by basal melt, the retrograde bed in a subglacial deep trough destabilized the Wordie Ice Shelf and led to grounding line retreat in 2010/2011 (Friedl et al., 2018). For the major calving event of the ice shelf in 1989, we observed stronger zonal winds between 1997-2008 compared to the reference period $(+0.62 \mathrm{~m} / \mathrm{s})$ and the most recent decade $(+0.28 \mathrm{~m} / \mathrm{s})(2009$ 2018). This means that during the breakup event the easterly wind direction weakened towards a more westerly direction. This change in wind direction causes upwelling of warm CDW and enhances basal melt, which is in line with the basal melt observed by the studies above. Additionally, we observed a positive SAM not only during 2008 to 2011, as in Walker and Gardner (2017), but also for the loss of the remaining ice tongues in summer 1998/1999. This strengthens the hypothesis that the retreat of Wordie Ice Shelf was influenced by environmental forcing through enhanced basal melt. We also observed a decreasing sea ice coverage $(-14 \mathrm{~d}$ compared to the reference mean) in the area of the former Wordie Ice Shelf, which has not been discussed in the literature but might have further facilitated the destabilization of the ice shelf margins. Despite strong evidence by observed environmental forcing, it shall not be neglected that the glaciers flowing into the former Wordie Ice Shelf are still, at least partly, responding to the collapse initiated in the 1960s.

The Wilkins Ice Shelf also experienced a series of calving events likely caused by environmental and buoyancy forces (Braun and Humbert, 2009; Scambos et al., 2000). Scambos et al. $(2000,2009)$ linked the calving event in summer 1998 to hydrofracture, which was due to surface melt and ponding caused by atmospheric forcing. In contrast, Braun et al. (2009) speculate that basal melt thinned the boundaries, and bending stresses from buoyancy forces caused the breakup in 1998. Additionally, the minimal extent of sea ice was discussed as a potential factor for retreat (Lucchitta and 
Rosanova, 1998). Our observations confirm the decrease in sea ice days $(-9 \mathrm{~d})$, potential basal melt through enhanced zonal winds $(+0.47 \mathrm{~m} / \mathrm{s})$, a peak in SAM, increased surface melt $(+0.06 \mathrm{~mm}$ w.e. per day $)$, higher sea surface temperatures $\left(+0.13^{\circ} \mathrm{C}\right)$, and increased air temperature $\left(+0.58^{\circ} \mathrm{C}\right)$ within the first decade compared to the reference time period. This suggests that the calving event in 1998 was probably forced by a combination of several environmental drivers that destabilized and thinned the ice shelf. Whether these factors alone would have caused the retreat or the additional stresses through buoyancy as stated by Braun et al. (2009) were necessary to initiated the final calving event remains unresolved. A second breakup event of the Wilkins Ice Shelf occurred in three stages during February, May, and June 2008 (Scambos et al., 2009), and the remaining ice bridge collapsed in April 2009 , likely due to mechanical external forcing by strong winds (Humbert et al., 2010). For the calving events in 2008, Scambos et al. (2009) found surface meltwater as the main pre-condition for calving, whereas Braun et al. (2009) excluded melt pond drainage as a driver and attribute the calving to fracture development and rift formation due to buoyancy forces and bending stresses through variable ice thickness. As described above, the surface melt only slightly increased between 1997-2008 compared to the reference period, which strengthens the hypothesis by Braun et al. (2009). Therefore, we suggest that a combination of glaciologically, environmentally, and mechanically forced processes caused the disintegration of Wilkins Ice Shelf.

The disintegration of Larsen B in 2002 is associated with increased surface melt causing enhanced fracturing (Khazendar et al., 2007; Rack and Rott, 2004) and widespread supraglacial lake drainage (Banwell et al., 2013; Leeson et al., 2020). Enhanced surface melt likely occurred as zonal winds were $+0.33 \mathrm{~m} / \mathrm{s}$ stronger, and a positive SAM anomaly occurred. Positive SAM years with stronger westerlies are not associated with upwelling at the Larsen $\mathrm{B}$ and $\mathrm{C}$ ice shelves but with warmer air temperatures in combination with warm winds and surface melt (Rack and Rott, 2004). Recent studies found that increases in foehn days in a series of years are related to positive SAM phases and significantly increase surface melt (Leeson et al., 2017; Cape et al., 2015). Interestingly, surface melt was high in the first decade, with up to $5 \mathrm{~mm}$ w.e. per day, but still lower than the values recorded during the reference period. The only difference was that the spatial distribution of surface melt changed slightly. Mean air temperature between 1997-2008 increased by $+0.16^{\circ} \mathrm{C}$ (within the uncertainties in the ERA5 data) during summer with no change in winter compared to the reference period. However, in the center of the ice shelf increases of up to $+0.49^{\circ} \mathrm{C}$ were observed during summer. The observed changes favor supraglacial lake formation as mentioned in the literature. It remains unclear whether the lake drainage observed shortly after is a cause or effect of ice shelf breakup (Leeson et al., 2020), and internal glaciologi- cal factors might also have played a role due to certain zones of weakness in the ice shelf (Khazendar et al., 2007).

In contrast stands the tabular calving event of iceberg A$68\left(\sim 5800 \mathrm{~km}^{2}\right)$ from Larsen C Ice Shelf, which accounted for almost the entire ice shelf extent decrease for the IIpp basin in 2009-2018 (see Fig. 2). The calving event was predictable as a decade earlier a rift developed from a crevasse field at the Gipps ice rise and propagated further until July 2017, when the iceberg calved (Hogg and Gudmundsson, 2017). In the period of the Larsen C calving event, we could not observe any environmental forcing as lower amounts of melt $(-0.2 \mathrm{~mm}$ w.e. per day), slightly stronger zonal winds of $+0.1 \mathrm{~m} / \mathrm{s}$, and decreased summer air temperatures $\left(-0.26^{\circ} \mathrm{C}\right)$ occurred compared to $1982-1996$. This strengthens the hypothesis of a natural calving event as proposed by Hogg and Gudmundsson (2017). Nevertheless, slight negative thickness changes were observed by Paolo et al. (2015) between 1994 and 2012, which could indicate a future weakening of the Larsen C Ice Shelf. Larsen D forms the only exception of the strong retreating trend along the Antarctic Peninsula. This ice shelf experienced neither melt nor positive trends in zonal winds. Positive thickness changes indicate so far no potential weakening through basal melt (Paolo et al., 2015). The mass balance of the Larsen D to $\mathrm{G}$ ice shelves is, depending on the study, positive (Gardner et al., 2018) to slightly negative but still smaller than the strong negative mass balance of the remaining Antarctic Peninsula (Rignot et al., 2019). Geroge VI and Stange ice shelves were relatively stable during 1997 to 2008 and started to retreat in 2009-2018. Slightly strengthening westerlies $(+0.25 \mathrm{~m} / \mathrm{s})$ but almost no melt $(0.02 \mathrm{~mm}$ w.e. per day) occurred within the second decade. Summer sea surface temperatures increased by +0.62 and $+0.38^{\circ} \mathrm{C}$ for George VI south and Stange ice shelves in the second decade compared to the reference period. The retreat rates of both ice shelves started to double the retreat rate during the second decade compared to the first. George VI is not believed to disintegrate rapidly (Holt et al., 2013). But recent developments might require reconsideration of this assumption because calving front retreat, recently detected supraglacial lakes on the ice shelf surface (Dirscherl et al., 2020), and moderate basal melt (Paolo et al., 2015) have occurred.

\subsection{West Antarctica}

Glacier and ice shelf front retreat of the WAIS is clearly dominant at Pine Island Bay and at the biggest Antarctic ice shelves (Ross and Ronne). Ross Ice Shelf lost an area of $\sim 14000 \mathrm{~km}^{2}$ between 1997 and 2008, which can be completely attributed to tabular iceberg calving of B15-B18 in 2000 and B19 in 2002 (in total $\sim 18000 \mathrm{~km}^{2}$ ) (Budge and Long, 2018; MacAyeal et al., 2001). Note that the difference in iceberg size versus retreated area arises from the rough estimation of iceberg area (width multiplied by length provided by the BYU Antarctic iceberg tracking database; Budge and 
Long, 2018) as well as the measurement over one decade where re-advance occurred after the calving event. The same applies for Ronne Ice Shelf, where the area $\left(\sim 12400 \mathrm{~km}^{2}\right)$ was lost by tabular iceberg calving of A38 and A39 (1998) and A43 and A44 (2000) with an area of $\sim 17500 \mathrm{~km}^{2}$ (Budge and Long, 2018; MacAyeal et al., 2001; Wuite et al., 2019). Even though the calved icebergs were of notable size (including the largest-ever recorded iceberg, B15) those calving events were not exceptional (MacAyeal et al., 2001). The Ross West Ice Shelf already experienced such a calving event before 1962, where the front had reached a similar position to that obtained in 2004 after its maximum extent around 1997 (Ferrigno et al., 2007). Also the maximum extent of the Ronne Ice Shelf was reached in 1997, and its minimum extents occurred in 1974 and 2004 (Ferrigno et al., 2005). Measurements of environmental conditions substantiate a natural calving event within the calving cycle of these ice shelves. We could observe neither a reduction in sea ice nor increases in sea surface temperature $\left(0.02^{\circ} \mathrm{C}\right)$ and zonal winds $(-0.15 \mathrm{~m} / \mathrm{s})$. Strong surface melt $(0.5 \mathrm{~mm}$ w.e. per day) occurred solely on the calved area of the Ronne Ice Shelf but was even higher between 1982 and 1996 at this location. It should be noted that Ronne and Filchner ice shelves might be prone to changing environmental conditions in the future as recent studies predict that the Ronne Ice Shelf will be affected by increasing basal melt through changing sea ice conditions and wind direction (Darelius et al., 2016).

A completely different setting occurs in the Pine Island Bay, where Pine Island and Thwaites glaciers showed strong retreat rates, with $40 \pm 0.15$ and $288 \pm 0.77 \mathrm{~km}^{2} / \mathrm{yr}$ between 1997 and 2018. The instability and unstoppable retreat of both glaciers has been suggested by several studies (Joughin et al., 2014; Milillo et al., 2019; Parizek et al., 2013; Rignot et al., 2014). The deep marine basin in combination with a retrograde slope creates an increased sensitivity to basal melt by ocean forcing. Our climatological analysis indicates potential upwelling of CDW through strengthening westerlies of $+0.28 \mathrm{~m} / \mathrm{s}$ in $1997-2008$ and $+0.25 \mathrm{~m} / \mathrm{s}$ in $2009-2018 \mathrm{com}-$ pared to the reference period. Additionally, sea surface temperatures increased by $+0.28^{\circ} \mathrm{C}$ at the front of Pine Island but only $+0.11^{\circ} \mathrm{C}$ at Thwaites Glacier from the first to the second decade. Notable changes in sea ice days or snowmelt were not observed. The sea surface temperature is especially important for the stability of the Thwaites Glacier tongue as it is currently stabilized by persistent fast ice, and the recent acceleration of the ice tongue is associated with changing ocean conditions (Miles et al., 2020). It has to be considered that the initial start of destabilization in Pine Island Bay occurred before our observation period as mass loss has occurred since 1979 (Rignot et al., 2019), new rifting areas were created in the beginning of the 1990s (Bindschadler, 2002; Rignot, 2002), and basal melt by ocean forcing has occurred at least since 1994 (Jacobs et al., 2011). Once marine ice sheet instability is initiated, changes in ocean forcing can no longer directly be linked to ice flow and hence calving front position
(Christianson et al., 2016). Moreover, as soon as the maximum ice thickness at the grounding line is reached through grounding line retreat on a retrograde bed, the terminus becomes unstable, and calving-induced frontal retreat has to be expected, which would no longer be coupled to environmentally forced basal melt (Bassis and Walker, 2012). Consequently, it cannot be ruled out that the measured frontal retreat over the last two decades is actually a response to earlier destabilization by ocean forcing. Nevertheless, our observations confirm that Pine Island and Thwaites glaciers are still exposed to ocean forcing.

Besides the fast-changing Amundsen Sea Sector, the Bellingshausen Sea Sector at Abbot Ice Shelf is less studied but also vulnerable to CDW forcing (Christie et al., 2016). Just recently, the velocity at the grounding line increased $(+20 \%, 2007-2014)$, a dynamic thinning signal evolved which is related to ice dynamics and lower snowfall (Chuter et al., 2017), and minor grounding line retreat has occurred (Christie et al., 2016). The recent dynamic thinning signal observed by Chuter et al. (2017) is in line with the glacier front retreat at Abbot Ice Shelf observed since the second decade, where westerlies increased by $+0.24 \mathrm{~m} / \mathrm{s}$ from the first to the second decade, indicating vulnerability to upwelling CDW. Other environmental variables did not change significantly. Along Marie Byrd Land the Getz Ice Shelf experienced strong grounding line retreat between 2003-2008 due to ocean forcing, which slowed down afterwards (2010 2015) (Christie et al., 2018). This pattern in ocean forcing is visible in our data as zonal winds reduced by $-0.41 \mathrm{~m} / \mathrm{s}$ from the first to the second decade. Interestingly, this is not apparent in the glacier front movement as glacier front retreat and advance were balanced between 1997 and 2008, but advance reduced from 103 to $73 \mathrm{~km}^{2} / \mathrm{yr}$ in the second decade. The lack of a clear signal in frontal retreat could be explained by several pinning points actioning to stabilize the ice shelf (Christie et al., 2018) as well as the low glacier flow velocity (Mouginot et al., 2019). We propose that those stabilized fronts require longer ocean forcing to respond with frontal retreat. The most stable ice shelves along West Antarctica are the Sulzberger and Nickerson ice shelves because a buffer to ocean forcing is provided by the bathymetry of the continental shelf (Christie et al., 2018). Additionally, they are floating in the cooler Ross Sea (Rignot et al., 2013). No increase in the measured potential environmental variables was observed over the last two decades in this region, which further strengthens the hypothesis that these stable ice shelves are not affected by environmental forcing.

\subsection{East Antarctica}

East Antarctica was long believed to represent the invulnerable part of Antarctica, with a stable discharge over the last years (Gardner et al., 2018). Recent mass balance estimations show that East Antarctica has been losing mass since 1979, with an increasing loss since 1999 (Rignot et al., 2019); how- 
ever altimeter measurements have recorded an almost stable mass balance for East Antarctica since 1992 (IMBIE, 2018). In contrast to the calving front retreat of West Antarctica and the Antarctic Peninsula, glacier and ice shelf front advance has dominated over the last two decades in East Antarctica. The regional differences are discussed in the following paragraphs and are shown in Fig. 2.

In Victoria Land, previous studies could not identify a trend in calving front location change and attributed observed changes to glacier size, terminus type, and local topographical settings (Fountain et al., 2017; Lovell et al., 2017). Our analysis strengthens the hypothesis that non-climatic drivers regulated calving front change along Victoria Land because no noticeable changes in sea ice, wind direction, snowmelt, and ocean surface temperatures were measured between 1997 and 2018 compared to the reference time period. The only noticeable change was the increase in summer $\left(+1.1^{\circ} \mathrm{C}\right)$ and winter $\left(+0.71{ }^{\circ} \mathrm{C}\right)$ air temperatures over the Mariner and Tucker glaciers during the second decade compared to 1982-1996, which did not influence the slight advance of Mariner Glacier and the stable front position of the Tucker Glacier.

Oats and George V Land have experienced a negative mass balance since 1999 (Rignot et al., 2019) but have not shown obvious trends in calving front position change. The calving front positions have been balanced over the last two decades, with switches between advance and retreat phases. A previous study by Lovell et al. (2017) noticed the potential influence of a decreased sea ice cover on the terminus position, but as we did not measure a significant change in sea ice, wind direction, sea surface temperature, or melt, the observed frontal changes cannot be connected to environmental forcing. Winter air temperature cooled by up to $-1^{\circ} \mathrm{C}$ and summer air temperature by up to $-0.49^{\circ} \mathrm{C}$ along the coast, but both frontal advance and retreat occurred. The only noticeable retreat occurred at Mertz Glacier tongue, which was caused by mechanical forcing due to an iceberg collision in 2010 (Giles, 2017).

The mass loss of East Antarctica is dominated by the loss in Wilkes Land being the only basin in EAIS loosing mass since 1979 (Rignot et al., 2019), where the majority of glaciers retreated between 2000 and 2012. This contrasting retreat compared to the rest of East Antarctica was linked to environmental forcing by a decrease in sea ice days (Miles et al., 2016). For Wilkes Land, we observed a simultaneous retreat in glacier fronts between 2009 and 2018 but could not link it to a decrease in sea ice days.

This might be due to the fact that during 1997-2008 sea ice days were only $\sim 5 \mathrm{~d}$ less than the reference mean as compared to the $\sim 34 \mathrm{~d}$ less between 2000 and 2012, as reported by Miles et al. (2016). This suggests that only extreme reductions in sea ice can be related to glacier retreat, implying that sea ice alone cannot be the only explanation for retreat along Wilkes Land. We propose that upwelling CDW weakened the glaciers by basal melt as a very strong positive tendency in zonal wind (with up to $+0.44 \mathrm{~m} / \mathrm{s}$ ) was observed in the second (but not in the first) decade compared to the reference mean. All other measured variables did not change significantly over the observation time period.

A strong retreat within the second decade occurred also at Glenzer Glacier next to Wilkes Land. The retreat is not yet mentioned in the literature, but satellite imagery reveals that an important pinning point was lost in 2004, and a rift started to propagate and led to a breakup event in April 2020. We suggest that the initial destabilization and loss of the pinning point were caused by an increase in zonal winds $(+0.32 \mathrm{~m} / \mathrm{s})$ as well as enhanced surface melt (up to $+0.4 \mathrm{~mm}$ w.e. per day) during the first decade. Increased zonal winds persisted during the second decade $(+1.23 \mathrm{~m} / \mathrm{s})$, indicating further ocean forcing. Nevertheless, the more recent calving event in April 2020 occurred due to a rift that developed over several years. Whether environmental drivers played a role or whether the rift developed due to ice flow acceleration initiated by the previous lost pinning point requires further investigation.

The fronts of Shackleton and West ice shelves advanced within the last two decades. Both ice shelves are stabilized by several pinning points. Recent studies found that supraglacial lake formation on the Shackleton Ice Shelf is closely connected to short-lived high-magnitude snowmelt events (Arthur et al., 2020). So far, the supraglacial lake coverage on the ice shelf is still small $(<1 \%)$, but it is proposed that widespread ponding and hydrofracture are likely to increase (Arthur et al., 2020). For both ice shelves we observed warmer air temperatures within the first and colder during the second decade (compared to the reference period). Snowmelt increased only locally along the margins of both ice shelves (up to $+0.3 \mathrm{~mm} / \mathrm{d}$ ). The strongest environmental forcing we observed within the second decade was zonal winds that strengthened by +0.97 and $+1.2 \mathrm{~m} / \mathrm{s}$ for the Shackleton and West ice shelves, respectively. The only indicator that weakening by basal melt occurred is the collapse of iceberg D- 15 . This iceberg calved in 1992 and remained there by reattaching to the West Ice Shelf but became unstable and split up in 2015 , which has been related to changes in the ocean environment (Walker et al., 2019). Shackleton shows first signs of instability as ice flow velocities increased by $43 \%$ between 1957-2016 (Rignot et al., 2019). Further investigations are necessary to prove that the measured enhanced zonal winds caused enhanced basal melt at both ice shelves or if other factors caused acceleration and the breakup of the iceberg.

The front of the Amery Ice Shelf gradually advanced between 1997 and 2018. The environmental conditions changed, with strengthening westerlies by $+0.26 \mathrm{~m} / \mathrm{s}$ in the second decade and increased snowmelt $(+0.23 \mathrm{~mm}$ w.e. per day) on the northern part of Amery ("Loose Tooth" region close to MacKenzie Bay; see Fig. 1) over the last two decades but a decrease in snowmelt $(-0.1 \mathrm{~mm}$ w.e. per day) in the southern region. The stability of the ice shelf is confirmed by velocity measurements, where no speed-up occurred since 
the 1970s (Rignot et al., 2019), and basal melt rates are low (Paolo et al., 2015), suggesting that the westerlies did not strengthen enough to cause upwelling CDW. In 2019, the tabular iceberg D-28 calved from the Amery Ice Shelf. This calving front retreat was predicted by Fricker et al. (2002) based on the observed rift propagation and regular calving cycle of the ice shelf. Still, it remains unclear if the observed increase in surface melt influenced the rift propagation in the Loose Tooth region. Prior to 2006, the rift propagation was not influenced by environmental forcing, but Bassis et al. (2008) did not exclude the potential influence of surface melt if the mean air temperature would rise above zero.

The area loss of Enderby Land is mostly attributed to the changes in Shirase Bay. Here, very contrasting changes appear, where the Prince Harald Ice Shelf retreats, and the Shirase Glacier advances, and vice versa. This was already mentioned by Jezek (2002). The only change in environmental conditions in this area occurred between 1997 and 2008, with an up to $+1 \mathrm{~mm}$ w.e. melt per day over Prince Edward Ice Shelf compared to the reference period. For Shirase Glacier no increases in melt were observed. In Shirase Bay, the specific glacier morphology and bed topography have been suggested to influence the calving regime rather than environmental factors (Nakamura et al., 2007).

Dronning Maud Land is dominated by advance over the entire study period. Historical records reveal that along Dronning Maud Land, phases of retreat and advance are typical, with larger calving events occurring between 1963 and the 1970s. Retreat continued until the 1990s, followed by a phase of advance (Miles et al., 2016; Kim et al., 2001). Goel et al. (2020) found that $95 \%$ of the fronts in Dronning Maud Land advanced between 2009 and 2014. Mass balance estimates also confirm phases fluctuating between mass loss and mass gain since 1979, with no evidence for long-term change (Rignot et al., 2019). In addition basal melt rate estimates confirm the relatively stable state of the ice shelves (Rignot et al., 2013; Paolo et al., 2015). Additional stability is given by the distribution of ice rises and rumples, and vulnerability to future unpinning exists for the Baudouin and Brunt ice shelves (see Fig. 2) (Goel et al., 2020). The environmental conditions along Dronning Maud Land changed only little in regards to sea ice days ( $-5 \mathrm{~d}$ in the first decade) and constant zonal winds between Shirase Bay and the Fimbul Ice Shelf and more negative winds $(\sim 0.35 \mathrm{~m} / \mathrm{s})$ between Jelbart and Filchner ice shelves (1997-2018 compared to the reference mean). The only exceptional change was observed for air temperature, which increased between Lazarev and Filchner ice shelves by between $+0.6-1.6^{\circ} \mathrm{C}$ in summer and $+0.9-1.8^{\circ} \mathrm{C}$ in winter within the second decade compared to the reference mean. Despite this remarkable increase in air temperature, ice shelf advance persisted as mean air temperatures were far below the freezing point, and surface melt did not increase.

\subsection{A circum-Antarctic perspective}

The above examples illustrate that environmental conditions have changed non-uniformly along the Antarctic coastline over the last two decades. Strengthening westerlies occurred along with frontal retreat at the western Antarctic Peninsula, Larsen B Ice Shelf, Pine Island Bay, Abbot Ice Shelf, and Wilkes Land, but advance has occurred at the Shackleton and West ice shelves. This pattern can be due to several reasons. Though strengthening zonal winds are a proxy for upwelling CDW (Spence et al., 2014), further studies are needed to assess the relationship between the magnitude of strengthening westerlies and the amount of basal melt resulting from that. Only a small increase in westerlies could be enough to increase basal melt considerably because basal melt has a nonlinear relationship with ocean temperature and can quadruple with only slight ocean warming (Jenkins et al., 2018). Additionally, the forcing by zonal winds is less strong in areas where CDW upwelling is less efficient due to strong tidal forcing (Hazel and Stewart, 2019; Stewart et al., 2018), and the local topography regulates the amount of CDW accessing the cavities of an ice shelf (Dutrieux et al., 2014). Moreover, the duration of required environmental forcing to cause destabilization of ice shelves solely by basal melt very likely exceeds the timescales addressed in this study. In addition, Shackleton and West ice shelves only experienced potential forcing by one driver, but it was found that the forcing by several environmental drivers had the greatest impact on calving front retreat of tidewater glaciers in Greenland (Cowton et al., 2018; Howat et al., 2008), which likely also applies for Antarctic ice shelves and glacier tongues. Further studies are necessary to assess the amount of basal melt for individual ice shelves as a result of strengthening westerlies.

Our study found a strong link between increased sea surface temperature and the occurrence of calving front retreat. The measured increases in sea surface temperature were between +0.15 and $+0.6^{\circ} \mathrm{C}$ per decade, which is still below the trend uncertainty stability of $0.01^{\circ} \mathrm{C}$ per year (Embury, 2019). The influences of warmer sea surface temperatures are twofold. Warmer sea surface temperatures lead to the melt of fast ice, which destabilizes glacier margins (Larour, 2004) and could result in retreat. Another explanation proposes that warm surface water increases melt at the waterline, which creates an overhanging ice cliff that is more likely to collapse (Mosbeux et al., 2020). Our results suggest that increased sea surface temperatures weakened the margins in the Bellingshausen and Amundsen sea sectors, where the highest increases in sea surface temperature were observed. Further destabilization could arise through the presence of marginal weakening rifts that become unstable (Lipovsky, 2020). Marginal weakening can also arise from a decrease in sea ice days which occurred along the western Antarctic Peninsula, the Bellingshausen and Amundsen sea sectors, and in Wilkes Land. Decreasing sea ice days occurred in conjunction with glacier and ice shelf retreat if the average re- 
duction per year was over $\sim 10 \mathrm{~d}$ or more within the decade. This might become important in the future. Recently, the turning point of an increasing Antarctic sea ice extent was reached (Parkinson, 2019; Ludescher et al., 2019).

Relative changes in mean air temperature could not be identified as a direct driver for calving front retreat even though increases of up to $+2{ }^{\circ} \mathrm{C}$ per decade were measured in some coastal areas (e.g., Dronning Maud Land, Victoria Land), which is beyond the uncertainty in the ERA5 air temperature data. This suggests that mean air temperature over a decade is not an appropriate way to assess the effect of air temperature on calving front change. This is because the relationship between air-temperature-driven surface melt and hydrofracture is known to destabilize ice shelves and can cause glacier front retreat (Arthur et al., 2020; Banwell et al., 2013; Leeson et al., 2020). More suitable would be the assessment of the number of positive degree days and extremetemperature events that directly influence surface melt on the ice shelf with more accurate and higher-resolution melt data. For example, catchment-wide melt and the resulting runoff had a higher impact on the retreat of Greenlandic glaciers than local air temperatures (Cowton et al., 2018).

Howat et al. (2008) found that peak events in air temperature and sea surface temperature can initialize glacier retreat. This study found that the absolute amount of snowmelt correlated significantly with glacier and ice shelf retreat but not relative changes in snowmelt. The detailed comparison of snowmelt with calving front retreat revealed strong melt during the decade of the breakup event (e.g., Larsen B and Wilkins ice shelves). Nevertheless, snowmelt was often higher during the reference period than during the actual calving event, which might indicate that longer phases of melt weaken the ice shelf over a longer time period (Leeson et al., 2017), and the intensity of surface melt events is of higher importance than just the presence of melt (Arthur et al., 2020). Moreover, the low resolution of melt data did not always match the actual calving front. We assume that the use of a not-up-to-date coastline product (e.g., at Larsen B) caused the inaccuracies over the ice shelf margins. Additionally, no information on the accuracy of the snowmelt product is provided, which makes the considered reanalysis data prone to potentially large biases. We suggest a more detailed study on glacier and ice shelf front change in combination with accurate high-resolution surface melt data (e.g., satellite-based surface melt estimates as published by Trusel et al., 2013) to capture all necessary surface hydrology processes including peak events of snowmelt. For example, it would be insightful to quantify the effect of ponding on ice shelf vulnerability rather than calculate the exact amount of melt (Joughin and Alley, 2011). Moreover, the hydrological system of the ice shelf has to be considered as river formation can act as a stabilizing mechanism by exporting meltwater to the ocean (Banwell, 2017), and hydrological processes such as lake drainage that occurred prior to the breakup event of Larsen B Ice Shelf have to be assessed further (Leeson et al.,
2020). These complex surface hydrological processes require much more detailed studies that consider the combination of factors mentioned above and do not solely focus on mean surface melt.

The identification of environmental drivers for calving front retreat presented a major challenge, and some questions remain unresolved due to the limitations of this study. The connection between atmospheric forcing and calving front retreat could not be entirely revealed as average surface melt and air temperatures did not allow for an analysis regarding threshold behavior (e.g., above-zero-degree days), peak events, and surface hydrological processes. Moreover, once ice shelf destabilization is initiated the response in frontal change may no longer be linearly connected to forcing and become decoupled from external forcings, as known for the marine ice sheet instability (Feldmann and Levermann, 2015; Joughin et al., 2014; Robel et al., 2019). As a result, the natural calving cycle and responses to environmental forcing may prevail on longer timescales than the ones addressed in this study. Those shortcomings were addressed by discussing the observed environmental changes in this study with information from previous studies, allowing the identification of key drivers for calving front retreat as not being solely environmentally driven but a combined result of complex interactions between internal ice dynamics, geometry, external mechanical forcing, and environmental drivers.

For future assessments of environmentally driven calving front change, it has to be considered that the environmental drivers with the potential to drive calving front retreat are closely connected to SAM and reinforced during positive SAM years. Extreme peaks in positive SAM can be connected to ice shelf disintegration, as has been shown for the Wordie Ice Shelf (Walker and Gardner, 2017), Larsen B Ice Shelf, and the first breakup event of Wilkins Ice Shelf. A positive SAM increases sea surface temperatures and air temperatures along the Antarctic Peninsula and West Antarctica. It also influences the sea ice cover, snowmelt, and the foehn effect as well as enhances westerly winds along the Antarctic coastline (Verdy et al., 2006; Kwok and Comiso, 2002; Marshall, 2007; Tedesco and Monaghan, 2009; Cape et al., 2015). Glacier and ice shelf retreat forced by environmental drivers will be even more likely in the future as rising greenhouse gases and ozone depletion will cause more positive phases of SAM (Paeth and Pollinger, 2010; Wang et al., 2014), further strengthening the identified environmental forces on calving front retreat.

\section{Conclusions}

For the first time, we present a circum-Antarctic record of calving front changes over the last two decades. Overall, the extent of the Antarctic Ice Sheet decreased by $-29618 \pm 1193 \mathrm{~km}^{2}$ between 1997 and 2008 and gained an area of $+7108 \pm 1029 \mathrm{~km}^{2}$ between 2009 and 2018 . Glacier 
and ice shelf front retreat concentrated along the Antarctic Peninsula and West Antarctica. The only East Antarctic coastal sector experiencing simultaneous calving front retreat of several glaciers was Wilkes Land in 2009-2018. The largest proportion of calving originated from Ross West and Ronne ice shelves, which were responsible for $75 \%$ of the West Antarctic loss during 1997 and 2008, but this loss was found to not be exceptional as similar minimum extents of the Ross and Ronne ice shelves occurred in the 1960s and 1970s, respectively. Decreasing sea ice days, strengthening westerlies, intense snowmelt, and increasing sea surface temperatures were identified as enabling driving forces for glacier and ice shelf front retreat along the Antarctic Peninsula, West Antarctica, and Wilkes Land. In contrast, changes in mean air temperature were not an appropriate measure for atmospheric forcing, and rather extreme temperature events, threshold behavior, and surface hydrological processes should be considered for future analysis. Further studies should assess whether record-high air temperatures can also trigger glacier and ice shelf retreat as has been observed for Greenland. Snowmelt was found to be a strong driver of calving front retreat in the Antarctic Peninsula (up to $5 \mathrm{~mm}$ w.e. per day), but more accurate data on surface melt and surface hydrology are needed to assess the influence of melt in more detail. Increased sea surface temperatures (by up to $+0.62^{\circ} \mathrm{C}$ ) were observed along the Bellingshausen and Amundsen sea sectors, weakening the glacier margins. Between 1997 and 2018, sea ice days decreased the most along the western Antarctic Peninsula (by up to $-25 \mathrm{~d})$, the Bellingshausen Sea Sector $(-10 \mathrm{~d})$, and Amundsen Sea Sector ( $-5 \mathrm{~d})$. Strengthening westerlies affected ice shelves along the western Antarctic Peninsula (up to $+0.54 \mathrm{~m} / \mathrm{s})$ and West Antarctica $(+0.28$ to $+0.41 \mathrm{~m} / \mathrm{s})$ but also in East Antarctica, particularly in Wilkes Land $(+0.44 \mathrm{~m} / \mathrm{s})$ and Queen Mary Land (up to $+1.23 \mathrm{~m} / \mathrm{s})$. Despite those changes in environmental conditions, the influence of internal ice dynamics, geometry, and external mechanical forcings play a crucial role and must not be neglected when assessing drivers of calving front retreat.

The assessed environmental drivers are closely connected to positive phases of SAM which occurred over the last two decades. Rising $\mathrm{CO}_{2}$ emissions and ozone depletion will further enhance positive phases of SAM, putting additional pressure on glaciers and ice shelves. To better assess the vulnerability of glaciers and ice shelves in the future, it is essential to better understand surface melt, ponding, and surface runoff processes that are impacting calving front retreat to an unknown extent. Equally important is the understanding of changing wind conditions and their impact on upwelling CDW and basal melt. Another interesting issue related to glacier and ice shelf changes across Antarctica pertains to their specific timescales and response times. A shortcoming of our analysis is the restriction to three snapshots of coastline data that has limited the scope of this study. Although our study has revealed that the Antarctic cryosphere has been subject to tremendous changes in recent decades, it is conceivable that our results are at least partly biased by strong inter-annual variability in all considered climate and cryospheric variables. In addition, natural cycles and the effects of man-made global warming may prevail on longer timescales over the ones we selected for this study on the basis of reasonable data coverage.

Data availability. The 2018 Antarctic coastline produced within this study is available at the EOC Geoservice of the German Aerospace Center (https://download.geoservice.dlr.de/icelines/ files/, last access: 17 May 2021, Baumhoer, 2021). The Supplement provides calving front changes for each assessed glacier and ice shelf in $\mathrm{m} / \mathrm{yr}$ and $\mathrm{km}^{2} / \mathrm{yr}$ (see Table S1).

The Radarsat (1997) and MODIS (2009) coastlines are available at https://nsidc.org/data/NSIDC-0103/versions/2 (Jezek et al., 2013) and https://nsidc.org/data/NSIDC-0593/versions/1 (Haran et al., 2014), respectively. Downloaded ERA5 data are available at the Copernicus Climate Data Store at https://cds.climate. copernicus.eu (Copernicus Climate Change Service, 2019a, b) and at the Ocean and Sea Ice Satellite Application Facility at https: //www.osi-saf.org/?q=content/sea-ice-products (OSI SAF, 2017). The BYU (Brigham Young University) Antarctic iceberg tracking database can be accessed at https://scp.byu.edu/data/iceberg/ database1.html (Budge and Long, 2018). The LIMA Landsat mosaic was downloaded from the USGS web page at https://lima.usgs. gov/fullcontinent.php (Bindschadler et al., 2008). The TanDEM-X PolarDEM $90 \mathrm{~m}$ was generated as described in Wessel et al. (2021) and is freely available at https://download.geoservice.dlr.de/TDM_ POLARDEM90/ANTARCTICA/ (last access: 12 March 2021).

Supplement. The supplement related to this article is available online at: https://doi.org/10.5194/tc-15-2357-2021-supplement.

Author contributions. CB designed the study, conducted the analysis, and wrote the original draft of the manuscript. $\mathrm{CK}$ and $\mathrm{AD}$ assisted in the study design. $\mathrm{CB}, \mathrm{CK}, \mathrm{AD}, \mathrm{CHK}$, and $\mathrm{HP}$ contributed to the discussion of the results and were involved in editing the manuscript.

Competing interests. The authors declare that they have no conflict of interest.

Acknowledgements. We thank the Copernicus Climate Data Store for providing the ERA5 climate data and the Ocean and Sea Ice Satellite Application Facility (OSI SAF) for providing the sea ice concentration data sets. In addition, we thank the European Union Copernicus program for providing Sentinel-1 data, accessible via the NASA Alaska Satellite Facility (ASF), and Gareth J. Marshall for granting open access to the Southern Annular Mode (SAM) index. Finally, we would like to thank the editor and especially Eleri Evans, Brad Lipovsky, and one anonymous reviewer for their comprehensive comments and suggestions on our manuscript. 
Financial support. The article processing charges for this openaccess publication were covered by the German Aerospace Center (DLR).

Review statement. This paper was edited by Kenichi Matsuoka and reviewed by Eleri Evans and one anonymous referee.

\section{References}

Alley, R. B., Horgan, H. J., Joughin, I., Cuffey, K. M., Dupont, T. K., Parizek, B. R., Anandakrishnan, S., and Bassis, J.: A simple law for ice-shelf calving, Science, 322, 1344-1344, 2008.

Arthur, J. F., Stokes, C. R., Jamieson, S. S. R., Carr, J. R., and Leeson, A. A.: Distribution and seasonal evolution of supraglacial lakes on Shackleton Ice Shelf, East Antarctica, The Cryosphere, 14, 4103-4120, https://doi.org/10.5194/tc-14-4103-2020, 2020.

Banwell, A.: Glaciology: Ice-shelf stability questioned, Nature, 544, 306-307, https://doi.org/doi.org/10.1038/544306a, 2017.

Banwell, A. F., MacAyeal, D. R., and Sergienko, O. V.: Breakup of the Larsen B Ice Shelf triggered by chain reaction drainage of supraglacial lakes, Geophys. Res. Lett., 40, 5872-5876, https://doi.org/10.1002/2013GL057694, 2013.

Bassis, J. N.: The statistical physics of iceberg calving and the emergence of universal calving laws, J. Glaciol., 57, 3-16, 2011.

Bassis, J. N. and Walker, C. C.: Upper and lower limits on the stability of calving glaciers from the yield strength envelope of ice, Proc. R. Soc.-Math. Phys. Eng. Sci., 468, 913-931, https://doi.org/10.1098/rspa.2011.0422, 2012.

Bassis, J. N., Fricker, H. A., Coleman, R., and Minster, J.-B.: An investigation into the forces that drive ice-shelf rift propagation on the Amery Ice Shelf, East Antarctica, J. Glaciol., 54, 17-27, 2008.

Baumhoer, C. A: IceLines Antarctic Coastline 2018, available at: https://download.geoservice.dlr.de/icelines/files/, last access: 17 May 2021.

Baumhoer, C. A., Dietz, A., Dech, S., and Kuenzer, C.: Remote Sensing of Antarctic Glacier and Ice-Shelf Front Dynamics - A Review, Remote Sens., 10, 1445, https://doi.org/10.3390/rs10091445, 2018.

Baumhoer, C. A., Dietz, A. J., Kneisel, C., and Kuenzer, C.: Automated Extraction of Antarctic Glacier and Ice Shelf Fronts from Sentinel-1 Imagery Using Deep Learning, Remote Sens., 11, 2529, https://doi.org/10.3390/rs11212529, 2019.

Belmonte Rivas, M. and Stoffelen, A.: Characterizing ERA-Interim and ERA5 surface wind biases using ASCAT, Ocean Sci., 15, 831-852, https://doi.org/10.5194/os-15-831-2019, 2019.

Benn, D. I., Warren, C. R., and Mottram, R. H.: Calving processes and the dynamics of calving glaciers, Earth-Sci. Rev., 82, 143179, 2007.

Bindschadler, R. A.: History of lower Pine Island Glacier, West Antarctica, from Landsat imagery, J. Glaciol., 48, 536-544, https://doi.org/10.3189/172756502781831052, 2002.

Bindschadler, R. A., Vornberger, P., Fleming, A., Fox, A., Mullins, J., Binnie, D., Paulsen, S. J., Granneman, B., and Gorodetzky, D.: The Landsat image mosaic of Antarctica, Remote Sens. Environ., 112, 4214-4226, 2008.
Brandt-Kreiner, M., Lavelle, J., Tonboe, R., Howe, E., Lavergne, T., Killie, M. A., Sorensen, A., Eastwood, S., and Neuville, A.: Global Sea Ice ConcentrationClimate Data RecordValidation Report, Climate Data Store, OSI-450 and OSI-430-b, Version 1.1, available at: http://osisaf.met.no/docs/osisaf_cdop3_ ss2_valrep_sea-ice-conc-climate-data-record_v1p1.pdf (last access: 20 March 2020), 2019.

Braun, M. and Humbert, A.: Recent Retreat of Wilkins Ice Shelf Reveals New Insights in Ice Shelf Breakup Mechanisms, IEEE Geosci. Remote Sens. Lett., 6, 263-267, https://doi.org/10.1109/LGRS.2008.2011925, 2009.

Braun, M., Humbert, A., and Moll, A.: Changes of Wilkins Ice Shelf over the past 15 years and inferences on its stability, The Cryosphere, 3, 41-56, https://doi.org/10.5194/tc-3-41-2009, 2009.

Budge, J. S. and Long, D. G.: A Comprehensive Database for Antarctic Iceberg Tracking Using Scatterometer Data, IEEE J. Sel. Top. Appl., 11, 434-442, https://doi.org/10.1109/JSTARS.2017.2784186, 2018.

Cape, M. R., Vernet, M., Skvarca, P., Marinsek, S., Scambos, T. A., and Domack, E.: Foehn winds link climate-driven warming to ice shelf evolution in Antarctica: Foehn winds link climate driven warming, J. Geophys. Res.-Atmos., 120, 11037-11057, https://doi.org/10.1002/2015JD023465, 2015.

Catania, G. A., Stearns, L. A., Sutherland, D. A., Fried, M. J., Bartholomaus, T. C., Morlighem, M., Shroyer, E., and Nash, J.: Geometric Controls on Tidewater Glacier Retreat in Central Western Greenland, J. Geophys. Res.-Earth, 123, 2024-2038, https://doi.org/10.1029/2017JF004499, 2018.

Christianson, K., Bushuk, M., Dutrieux, P., Parizek, B. R., Joughin, I. R., Alley, R. B., Shean, D. E., Abrahamsen, E. P., Anandakrishnan, S., Heywood, K. J., Kim, T.-W., Lee, S. H., Nicholls, K., Stanton, T., Truffer, M., Webber, B. G. M., Jenkins, A., Jacobs, S., Bindschadler, R. A., and Holland, D. M.: Sensitivity of Pine Island Glacier to observed ocean forcing: PIG response to ocean forcing, Geophys. Res. Lett., 43, 10817-10825, https://doi.org/10.1002/2016GL070500, 2016.

Christie, F. D. W., Bingham, R. G., Gourmelen, N., Tett, S. F. B., and Muto, A.: Four-decade record of pervasive grounding line retreat along the Bellingshausen margin of West Antarctica: West Antarctic Ice Retreat, Geophys. Res. Lett., 43, 5741-5749, https://doi.org/10.1002/2016GL068972, 2016.

Christie, F. D. W., Bingham, R. G., Gourmelen, N., Steig, E. J., Bisset, R. R., Pritchard, H. D., Snow, K., and Tett, S. F. B.: Glacier change along West Antarctica's Marie Byrd Land Sector and links to inter-decadal atmosphere-ocean variability, The Cryosphere, 12, 2461-2479, https://doi.org/10.5194/tc-12-24612018, 2018.

Chuter, S. J., Martín-Español, A., Wouters, B., and Bamber, J. L.: Mass balance reassessment of glaciers draining into the $\mathrm{Ab}$ bot and Getz Ice Shelves of West Antarctica: Getz and Abbot Mass Balance Reassessment, Geophys. Res. Lett., 44, 73287337, https://doi.org/10.1002/2017GL073087, 2017.

Cook, A. J. and Vaughan, D. G.: Overview of areal changes of the ice shelves on the Antarctic Peninsula over the past 50 years, The Cryosphere, 4, 77-98, https://doi.org/10.5194/tc-4-77-2010, 2010. 
Cook, A. J., Holland, P. R., Meredith, M. P., Murray, T., Luckman, A., and Vaughan, D. G.: Ocean forcing of glacier retreat in the western Antarctic Peninsula, Science, 353, 283-286, 2016.

Copernicus Climate Change Service: ERA5 monthly averaged data on single levels from 1979 to present, Climate Data Store, https://doi.org/10.24381/CDS.F17050D7, 2019a.

Copernicus Climate Change Service: ERA5-Land monthly averaged data from 1981 to present, Climate Data Store, https://doi.org/10.24381/CDS.68D2BB30, 2019b.

Cowton, T. R., Sole, A. J., Nienow, P. W., Slater, D. A., and Christoffersen, P.: Linear response of east Greenland's tidewater glaciers to ocean/atmosphere warming, P. Natl. Acad. Sci. USA, 115, 7907-7912, https://doi.org/10.1073/pnas.1801769115, 2018.

Darelius, E., Fer, I., and Nicholls, K. W.: Observed vulnerability of Filchner-Ronne Ice Shelf to wind-driven inflow of warm deep water, Nat. Commun., 7, 12300, https://doi.org/10.1038/ncomms12300, 2016.

De Angelis, H. and Skvarca, P.: Glacier Surge After Ice Shelf Collapse, Science, 299, 1560-1562, https://doi.org/10.1126/science.1077987, 2003.

Depoorter, M. A., Bamber, J. L., Griggs, J. A., Lenaerts, J. T. M., Ligtenberg, S. R. M., Van den Broeke, M. R., and Moholdt, G.: Calving fluxes and basal melt rates of Antarctic ice shelves, Nature, 502, p. 89, https://doi.org/10.1038/nature12567, 2013.

De Rydt, J., Gudmundsson, G. H., Rott, H., and Bamber, J. L.: Modeling the instantaneous response of glaciers after the collapse of the Larsen B Ice Shelf, Geophys. Res. Lett., 42, 5355-5363, https://doi.org/10.1002/2015GL064355, 2015.

Dirscherl, M., Dietz, A. J., Kneisel, C., and Kuenzer, C.: Automated Mapping of Antarctic Supraglacial Lakes Using a Machine Learning Approach, Remote Sens., 12, 1203, https://doi.org/10.3390/rs12071203, 2020.

Domack, E., Duran, D., Leventer, A., Ishman, S., Doane, S., McCallum, S., Amblas, D., Ring, J., Gilbert, R., and Prentice, M.: Stability of the Larsen B ice shelf on the Antarctic Peninsula during the Holocene epoch, Nature, 436, 681-685, https://doi.org/10.1038/nature03908, 2005.

Dutrieux, P., De Rydt, J., Jenkins, A., Holland, P. R., Ha, H. K., Lee, S. H., Steig, E. J., Ding, Q., Abrahamsen, E. P., and Schroder, M.: Strong Sensitivity of Pine Island IceShelf Melting to Climatic Variability, Science, 343, 174-178, https://doi.org/10.1126/science.1244341, 2014.

Embury, O.: Product Quality Assessment Report, Sea Surface Temperature, available at: https://datastore.copernicus-climate.eu/ documents/satellite-sea-surface-temperature/v2.0/D2.SST.2-v2. 2_PQAR_of_v2SST_products_v4.1_APPROVED_Ver1.pdf (last access: 17 May 2021), 28 September 2019.

Feldmann, J. and Levermann, A.: Collapse of the West Antarctic Ice Sheet after local destabilization of the Amundsen Basin, P. Natl. Acad. Sci. USA, 112, 14191-14196, https://doi.org/10.1073/pnas.1512482112, 2015.

Ferrigno, J., Foley, K. M., Swithinbank, C., Williams Jr., R. S., and Dailide, L.: Coastal-Change And Glaciological Map Of The Ronne Ice Shelf Area, Antarctica: 1974-2002, USGS Coast. Change Maps, I-2600-D, 1-11, 2005.

Ferrigno, J., Foley, K. M., Swithinbank, C., and Williams Jr., R. S.: Coastal-Change and Glaciological Mapof the Northern Ross Ice Shelf Area,Antarctica: 1962-2004, USGS Coast. Change Maps, 1-11, 2007.
Fountain, A. G., Glenn, B., and Scambos, T. A.: The changing extent of the glaciers along the western Ross Sea, Antarctica, Geology, 45, 927-930, 2017.

Fricker, H. A., Young, N. W., Allison, I., and Coleman, R.: Iceberg calving from the Amery Ice Shelf, East Antarctica, Ann. Glaciol., 34, 241-246, https://doi.org/10.3189/172756402781817581, 2002.

Friedl, P., Seehaus, T. C., Wendt, A., Braun, M. H., and Höppner, K.: Recent dynamic changes on Fleming Glacier after the disintegration of Wordie Ice Shelf, Antarctic Peninsula, The Cryosphere, 12, 1347-1365, https://doi.org/10.5194/tc-12-1347-2018, 2018.

Fürst, J. J., Durand, G., Gillet-Chaulet, F., Tavard, L., Rankl, M., Braun, M., and Gagliardini, O.: The safety band of Antarctic ice shelves, Nat. Clim. Change, 6, 479-482, 2016.

Gagliardini, O., Durand, G., Zwinger, T., Hindmarsh, R. C. A., and Le Meur, E.: Coupling of ice-shelf melting and buttressing is a key process in ice-sheets dynamics, Geophys. Res. Lett., 37, https://doi.org/10.1029/2010gl043334, 2010.

Gardner, A. S., Moholdt, G., Scambos, T., Fahnstock, M., Ligtenberg, S., van den Broeke, M., and Nilsson, J.: Increased West Antarctic and unchanged East Antarctic ice discharge over the last 7 years, The Cryosphere, 12, 521-547, https://doi.org/10.5194/tc-12-521-2018, 2018.

Giles, A. B.: The Mertz Glacier Tongue, East Antarctica. Changes in the past 100 years and its cyclic nature Past, present and future, Remote Sens. Environ., 191, 30-37, https://doi.org/10.1016/j.rse.2017.01.003, 2017.

Goel, V., Matsuoka, K., Berger, C. D., Lee, I., Dall, J., and Forsberg, R.: Characteristics of ice rises and ice rumples in Dronning Maud Land and Enderby Land, Antarctica, J. Glaciol., 66, 1064-1078, https://doi.org/10.1017/jog.2020.77, 2020.

Gossart, A., Helsen, S., Lenaerts, J. T. M., Broucke, S. V., van Lipzig, N. P. M., and Souverijns, N.: An Evaluation of Surface Climatology in State-of-the-Art Reanalyses over the Antarctic Ice Sheet, J. Climate, 32, 6899-6915, https://doi.org/10.1175/JCLI-D-19-0030.1, 2019.

Haran, T., Bohlander, J., Scambos, T., Painter, T., and Fahnestock, M.: MODIS Mosaic of Antarctica 2008-2009 (MOA2009) Image Map, Version 1, [Antarctic Coastline 2009], NSIDC: National Snow and Ice Data Center, Boulder, Colorado USA, https://doi.org/10.7265/N5KP8037, 2014.

Hazel, J. E. and Stewart, A. L.: Are the Near-Antarctic Easterly Winds Weakening in Response to Enhancement of the Southern Annular Mode?, J. Climate, 32, 1895-1918, https://doi.org/10.1175/JCLI-D-18-0402.1, 2019.

Hersbach, H., Bell, B., Berrisford, P., Hirahara, S., Horányi, A., Muñoz-Sabater, J., Nicolas, J., Peubey, C., Radu, R., Schepers, D., Simmons, A., Soci, C., Abdalla, S., Abellan, X., Balsamo, G., Bechtold, P., Biavati, G., Bidlot, J., Bonavita, M., Chiara, G., Dahlgren, P., Dee, D., Diamantakis, M., Dragani, R., Flemming, J., Forbes, R., Fuentes, M., Geer, A., Haimberger, L., Healy, S., Hogan, R. J., Hólm, E., Janisková, M., Keeley, S., Laloyaux, P., Lopez, P., Lupu, C., Radnoti, G., Rosnay, P., Rozum, I., Vamborg, F., Villaume, S., and Thépaut, J.: The ERA5 global reanalysis, Q. J. Roy. Meteor. Soc., 146, 1999-2049, https://doi.org/10.1002/qj.3803, 2020.

Hogg, A. E. and Gudmundsson, G. H.: Impacts of the LarsenC Ice Shelf calving event, Nat. Clim. Change, 7, 540-542, https://doi.org/10.1038/nclimate3359, 2017. 
Holt, T. O., Glasser, N. F., Quincey, D. J., and Siegfried, M. R.: Speedup and fracturing of George VI Ice Shelf, Antarctic Peninsula, The Cryosphere, 7, 797-816, https://doi.org/10.5194/tc-7797-2013, 2013.

Howat, I. M., Joughin, I., Fahnestock, M., Smith, B. E., and Scambos, T. A.: Synchronous retreat and acceleration of southeast Greenland outlet glaciers 2000-06: ice dynamics and coupling to climate, J. Glaciol., 54, 646-660, https://doi.org/10.3189/002214308786570908, 2008.

Hughes, T.: The weak underbelly of the West Antarctic ice sheet, J. Glaciol., 27, 518-525, 1981.

Humbert, A., Gross, D., Müller, R., Braun, M., van de Wal, R. S. W., van den Broeke, M. R., Vaughan, D. G., and van de Berg, W. J.: Deformation and failure of the ice bridge on the Wilkins Ice Shelf, Antarctica, Ann. Glaciol., 51, 49-55, https://doi.org/10.3189/172756410791392709, 2010.

IMBIE: Mass balance of the Antarctic Ice Sheet from 1992 to 2017, Nature, 558, 219-222, https://doi.org/10.1038/s41586018-0179-y, 2018.

Jacobs, S. S., Jenkins, A., Giulivi, C. F., and Dutrieux, P.: Stronger ocean circulation and increased melting under Pine Island Glacier ice shelf, Nat. Geosci., 4, 519-523, 2011.

Jenkins, A., Shoosmith, D., Dutrieux, P., Jacobs, S., Kim, T. W., Lee, S. H., Ha, H. K., and Stammerjohn, S.: West Antarctic Ice Sheet retreat in the Amundsen Sea driven by decadal oceanic variability, Nat. Geosci., 11, 733-738, https://doi.org/10.1038/s41561-018-0207-4, 2018.

Jezek, K. C.: RADARSAT-1 Antarctic Mapping Project: changedetection and surface velocity campaign, Ann. Glaciol., 34, 263268, 2002.

Jezek, K. C., Curlander, J. C., Carsey, F., Wales, C., and Barry, R. G.: RAMP AMM-1 SAR Image Mosaic of Antarctica, Version 2, [Antarctic Coastline 1997], NASA National Snow and Ice Data Center Distributed Active Archive Center, Boulder, Colorado, https://doi.org/10.5067/8AF4ZRPULS4H, 2013.

Joughin, I. and Alley, R. B.: Stability of the West Antarctic ice sheet in a warming world, Nat. Geosci., 4, 506-513, 2011.

Joughin, I. and MacAyeal, D. R.: Calving of large tabular icebergs from ice shelf rift systems, Geophys. Res. Lett., 32, L02501, https://doi.org/10.1029/2004GL020978, 2005.

Joughin, I., Smith, B. E., and Medley, B.: Marine Ice Sheet Collapse Potentially Under Way for the Thwaites Glacier Basin, West Antarctica, Science, 344, 735-738, https://doi.org/10.1126/science.1249055, 2014.

Khazendar, A., Rignot, E., and Larour, E.: Larsen B Ice Shelf rheology preceding its disintegration inferred by a control method, Geophys. Res. Lett., 34, L19503, https://doi.org/10.1029/2007GL030980, 2007.

Kim, K. T., Jezek, K. C., and Sohn, H. G.: Ice shelf advance and retreat rates along the coast of Queen Maud Land, Antarctica, J. Geophys. Res.-Oceans, 106, 7097-7106, https://doi.org/10.1029/2000JC000317, 2001.

Konrad, H., Shepherd, A., Gilbert, L., Hogg, A. E., McMillan, M., Muir, A., and Slater, T.: Net retreat of Antarctic glacier grounding lines, Nat. Geosci., 11, 258-258, 2018.

Kopp, R. E., DeConto, R. M., Bader, D. A., Hay, C. C., Horton, R. M., Kulp, S., Oppenheimer, M., Pollard, D., and Strauss, B. H.: Evolving Understanding of Antarctic Ice-Sheet Physics and
Ambiguity in Probabilistic Sea-Level Projections, Earths Future, 5, 1217-1233, https://doi.org/10.1002/2017EF000663, 2017.

Kwok, R. and Comiso, J. C.: Spatial patterns of variability in Antarctic surface temperature: Connections to the Southern Hemisphere Annular Mode and the Southern Oscillation: Antarctic Surface Temperature, Geophys. Res. Lett., 29, 50-150-4, https://doi.org/10.1029/2002GL015415, 2002.

Larour, E.: Modelling of rift propagation on Ronne Ice Shelf, Antarctica, and sensitivity to climate change, Geophys. Res. Lett., 31, L16404, https://doi.org/10.1029/2004GL020077, 2004.

Lavergne, T., Sørensen, A. M., Kern, S., Tonboe, R., Notz, D., Aaboe, S., Bell, L., Dybkjær, G., Eastwood, S., Gabarro, C., Heygster, G., Killie, M. A., Brandt Kreiner, M., Lavelle, J., Saldo, R., Sandven, S., and Pedersen, L. T.: Version 2 of the EUMETSAT OSI SAF and ESA CCI sea-ice concentration climate data records, The Cryosphere, 13, 49-78, https://doi.org/10.5194/tc-13-49-2019, 2019.

Leeson, A. A., Van Wessem, J. M., Ligtenberg, S. R. M., Shepherd, A., Van Den Broeke, M. R., Killick, R., Skvarca, P., Marinsek, S., and Colwell, S.: Regional climate of the Larsen B embayment 1980-2014, J. Glaciol., 63, 683-690, https://doi.org/10.1017/jog.2017.39, 2017.

Leeson, A. A., Forster, E., Rice, A., Gourmelen, N., and Wessem, J. M.: Evolution of Supraglacial Lakes on the Larsen B Ice Shelf in the Decades Before it Collapsed, Geophys. Res. Lett., 47, e2019GL085591, https://doi.org/10.1029/2019GL085591, 2020.

Lipovsky, B. P.: Ice shelf rift propagation: stability, threedimensional effects, and the role of marginal weakening, The Cryosphere, 14, 1673-1683, https://doi.org/10.5194/tc-14-16732020, 2020.

Liu, H. and Jezek, K. C.: A complete high-resolution coastline of Antarctica extracted from orthorectified Radarsat SAR imagery, Photogramm. Eng. Rem. S., 70, 605-616, https://doi.org/10.14358/pers.70.5.605, 2004.

Liu, Y., Moore, J. C., Cheng, X., Gladstone, R. M., Bassis, J. N., Liu, H., Wen, J., and Hui, F.: Ocean-driven thinning enhances iceberg calving and retreat of Antarctic ice shelves, P. Natl. Acad. Sci. USA, 112, 3263-3268, 2015.

Lovell, A. M., Stokes, C. R., and Jamieson, S. S. R.: Sub-decadal variations in outlet glacier terminus positions in Victoria Land, Oates Land and George V Land, East Antarctica (1972-2013), Antarct. Sci., 29, 468-483, https://doi.org/10.1017/S0954102017000074, 2017.

Lucchitta, B. K. and Rosanova, C. E.: Retreat of northern margins of George VI and Wilkins Ice Shelves, Antarctic Peninsula, Ann. Glaciol., 27, 41-46, 1998.

Luckman, A., Benn, D. I., Cottier, F., Bevan, S., Nilsen, F., and Inall, M.: Calving rates at tidewater glaciers vary strongly with ocean temperature, Nat. Commun., 6, 8566, https://doi.org/10.1038/ncomms9566, 2015.

Ludescher, J., Yuan, N., and Bunde, A.: Detecting the statistical significance of the trends in the Antarctic sea ice extent: an indication for a turning point, Clim. Dynam., 53, 237-244, https://doi.org/10.1007/s00382-018-4579-3, 2019.

MacAyeal, D. R., Padman, L., Drinkwater, M., Fahnestock, M., Gotis, T. T., A., Gray, L., Kerman, B., Lazzara, M., Rignot, E., Scambos, T., and Stearns, C.: Effects of Rigid Body Collisions and Tide-Forced Drift on Large Tabular Icebergs of the Antarctic, The University of Chicago, Department of the Geophysical Sci- 
ences, available at: http://geosci.uchicago.edu/ drm7/research/ Icebergs_of_Y2k.pdf (last access: 2 December 2020), 2001.

Marshall, G. J.: Trends in the Southern Annular Mode from Observations and Reanalyses, J. Climate, $16, \quad 4134-4143$, https://doi.org/10.1175/15200442(2003)016<4134:TITSAM>2.0.CO;2, 2003.

Marshall, G. J.: Half-century seasonal relationships between the Southern Annular mode and Antarctic temperatures, Int. J. Climatol., 27, 373-383, https://doi.org/10.1002/joc.1407, 2007.

Marshall, G. J.: The Climate Data Guide: Marshall Southern Annular Mode (SAM) Index (Station-based), edited by: National Center for Atmospheric Research Staff, available at: https://climatedataguide.ucar.edu/climate-data/ marshall-southern-annular-mode-sam-index-station-based (last access: 5 March 2020), 2018.

Massom, R., Reid, P., Stammerjohn, S., Raymond, B., Fraser, A., and Ushio, S.: Change and Variability in East Antarctic Sea Ice Seasonality, 1979/80-2009/10, PLoS ONE, 8, e64756, https://doi.org/10.1371/journal.pone.0064756, 2013.

Massom, R. A., Giles, A. B., Warner, R. C., Fricker, H. A., Legresy, B., Hyland, G., Lescarmontier, L., and Young, N.: External influences on the Mertz Glacier Tongue (East Antarctica) in the decade leading up to its calving in 2010, J. Geophys. Res.-Earth, 120, 490-506, https://doi.org/10.1002/2014JF003223, 2015.

Massom, R. A., Scambos, T. A., Bennetts, L. G., Reid, P., Squire, V. A., and Stammerjohn, S. E.: Antarctic ice shelf disintegration triggered by sea ice loss and ocean swell, Nature, 558, 383-389, https://doi.org/10.1038/s41586-018-0212-1, 2018.

Matsuoka, K., Hindmarsh, R. C. A., Moholdt, G., Bentley, M. J., Pritchard, H. D., Brown, J., Conway, H., Drews, R., Durand, G., Goldberg, D., Hattermann, T., Kingslake, J., Lenaerts, J. T. M., Martín, C., Mulvaney, R., Nicholls, K. W., Pattyn, F., Ross, N., Scambos, T., and Whitehouse, P. L.: Antarctic ice rises and rumples: Their properties and significance for icesheet dynamics and evolution, Earth-Sci. Rev., 150, 724-745, https://doi.org/10.1016/j.earscirev.2015.09.004, 2015.

Mercer, J. H.: West Antarctic ice sheet and $\mathrm{CO}_{2}$ greenhouse effect: a threat of disaster, Nature, 271, 321-325, 1978.

Miles, B. W. J., Stokes, C. R., and Jamieson, S. S. R.: Pan-icesheet glacier terminus change in East Antarctica reveals sensitivity of Wilkes Land to sea-ice changes, Sci. Adv., 2, e1501350, https://doi.org/10.1126/sciadv.1501350, 2016.

Miles, B. W. J., Stokes, C. R., Jenkins, A., Jordan, J. R., Jamieson, S. S. R., and Gudmundsson, G. H.: Intermittent structural weakening and acceleration of the Thwaites Glacier Tongue between 2000 and 2018, J. Glaciol., 66, 1-11, https://doi.org/10.1017/jog.2020.20, 2020.

Milillo, P., Rignot, E., Rizzoli, P., Scheuchl, B., Mouginot, J., Bueso-Bello, J., and Prats-Iraola, P.: Heterogeneous retreat and ice melt of Thwaites Glacier, West Antarctica, Sci. Adv., 5, eaau3433, https://doi.org/10.1126/sciadv.aau3433, 2019.

Mosbeux, C., Wagner, T. J. W., Becker, M. K., and Fricker, H. A.: Viscous and elastic buoyancy stresses as drivers of ice-shelf calving, J. Glaciol., 1-15, https://doi.org/10.1017/jog.2020.35, 2020.

Mouginot, J.: MEaSURES Antarctic Boundaries for IPY 2007-2009 from Satellite Radar, Version 2, https://doi.org/10.5067/AXE4121732AD, 2017.

Mouginot, J., Rignot, E., and Scheuchl, B.: ContinentWide, Interferometric SAR Phase, Mapping of Antarc- tic Ice Velocity, Geophys. Res. Lett., 46, 9710-9718, https://doi.org/10.1029/2019GL083826, 2019.

Nakamura, K., Doi, K., and Shibuya, K.: Why is Shirase Glacier turning its flow direction eastward?, Polar Sci., 1, 63-71, https://doi.org/10.1016/j.polar.2007.09.003, 2007.

OSI SAF: OSI-450 Global Sea Ice Concentration Climate Data Record v2.0 - Multimission (2.0), https://doi.org/10.15770/EUM_SAF_OSI_0008, 2017.

Paeth, H. and Pollinger, F.: Enhanced evidence in climate models for changes in extratropical atmospheric circulation, Tellus Dyn. Meteorol. Oceanogr., 62, 647-660, https://doi.org/10.1111/j.1600-0870.2010.00455.x, 2010.

Paolo, F. S., Fricker, H. A., and Padman, L.: Volume loss from Antarctic ice shelves is accelerating, Science, 348, 327-331, 2015.

Parizek, B. R., Christianson, K., Anandakrishnan, S., Alley, R. B., Walker, R. T., Edwards, R. A., Wolfe, D. S., Bertini, G. T., Rinehart, S. K., Bindschadler, R. A., and Nowicki, S. M. J.: Dynamic (in)stability of Thwaites Glacier, West Antarctica: Thwaites Dynamics, J. Geophys. Res.-Earth, 118, 638-655, https://doi.org/10.1002/jgrf.20044, 2013.

Parkinson, C. L.: A 40-y record reveals gradual Antarctic sea ice increases followed by decreases at rates far exceeding the rates seen in the Arctic, P. Natl. Acad. Sci. USA, 116, 14414-14423, https://doi.org/10.1073/pnas.1906556116, 2019.

Pattyn, F., Ritz, C., Hanna, E., Asay-Davis, X., DeConto, R., Durand, G., Favier, L., Fettweis, X., Goelzer, H., Golledge, N. R., Munneke, P. K., Lenaerts, J. T. M., Nowicki, S., Payne, A. J., Robinson, A., Seroussi, H., Trusel, L. D., and Broeke, M. van den: The Greenland and Antarctic ice sheets under $1.5^{\circ} \mathrm{C}$ global warming, Nat. Clim. Change, 1, https://doi.org/10.1038/s41558018-0305-8, 2018.

Pollard, D., DeConto, R. M., and Alley, R. B.: Potential Antarctic Ice Sheet retreat driven by hydrofracturing and ice cliff failure, Earth Planet. Sc. Lett., 412, 112-121, https://doi.org/10.1016/j.epsl.2014.12.035, 2015.

Rack, W. and Rott, H.: Pattern of retreat and disintegration of the Larsen B ice shelf, Antarctic Peninsula, Ann. Glaciol., 39, 505510, 2004.

Rankl, M., Fürst, J. J., Humbert, A., and Braun, M. H.: Dynamic changes on the Wilkins Ice Shelf during the 2006-2009 retreat derived from satellite observations, The Cryosphere, 11, 11991211, https://doi.org/10.5194/tc-11-1199-2017, 2017.

Rignot, E.: Ice-shelf changes in Pine Island Bay, Antarctica, 1947-2000, J. Glaciol., 48, 247-256, https://doi.org/10.3189/172756502781831386, 2002.

Rignot, E., Mouginot, J., and Scheuchl, B.: Ice Flow of the Antarctic Ice Sheet, Science, 333, 1427-1430, https://doi.org/10.1126/science.1208336, 2011.

Rignot, E., Jacobs, S., Mouginot, J., and Scheuchl, B.: IceShelf Melting Around Antarctica, Science, 341, 266-270, https://doi.org/10.1126/science.1235798, 2013.

Rignot, E., Mouginot, J., Morlighem, M., Seroussi, H., and Scheuchl, B.: Widespread, rapid grounding line retreat of Pine Island, Thwaites, Smith, and Kohler glaciers, West Antarctica, from 1992 to 2011, Geophys. Res. Lett., 41, 3502-3509, https://doi.org/10.1002/2014GL060140, 2014.

Rignot, E., Mouginot, J., Scheuchl, B., van den Broeke, M., van Wessem, M. J., and Morlighem, M.: Four 
decades of Antarctic Ice Sheet mass balance from 1979-2017, P. Natl. Acad. Sci. USA, 116, 1095-1103, https://doi.org/10.1073/pnas.1812883116, 2019.

Robel, A. A., Seroussi, H., and Roe, G. H.: Marine ice sheet instability amplifies and skews uncertainty in projections of future sea-level rise, P. Natl. Acad. Sci. USA, 116, 14887-14892, https://doi.org/10.1073/pnas.1904822116, 2019.

Rosier, S. H. R., Green, J. A. M., Scourse, J. D., and Winkelmann, R.: Modeling Antarctic tides in response to ice shelf thinning and retreat, J. Geophys. Res.-Oceans, 119, 87-97, https://doi.org/10.1002/2013JC009240, 2014.

Rott, H., Müller, F., Nagler, T., and Floricioiu, D.: The imbalance of glaciers after disintegration of Larsen-B ice shelf, Antarctic Peninsula, The Cryosphere, 5, 125-134, https://doi.org/10.5194/tc-5-125-2011, 2011.

Royston, S. and Gudmundsson, G. H.: Changes in ice-shelf buttressing following the collapse of Larsen A Ice Shelf, Antarctica, and the resulting impact on tributaries, J. Glaciol., 62, 905-911, 2016.

Scambos, T. A., Hulbe, C., Fahnestock, M., and Bohlander, J.: The link between climate warming and break-up of ice shelves in the Antarctic Peninsula, J. Glaciol., 46, 516-530, https://doi.org/10.3189/172756500781833043, 2000.

Scambos, T. A., Haran, T. M., Fahnestock, M. A., Painter, T. H., and Bohlander, J.: MODIS-based Mosaic of Antarctica (MOA) data sets: Continent-wide surface morphology and snow grain size, Remote Sens. Environ., 111, 242-257, https://doi.org/10.1016/j.rse.2006.12.020, 2007.

Scambos, T. A., Fricker, H. A., Liu, C.-C., Bohlander, J., Fastook, J., Sargent, A., Massom, R., and Wu, A.-M.: Ice shelf disintegration by plate bending and hydro-fracture: Satellite observations and model results of the 2008 Wilkins ice shelf break-ups, Earth Planet. Sc. Lett., 280, 51-60, https://doi.org/10.1016/j.epsl.2008.12.027, 2009.

Scambos, T. A., Bell, R. E., Alley, R. B., Anandakrishnan, S., Bromwich, D. H., Brunt, K., Christianson, K., Creyts, T., Das, S. B., DeConto, R., Dutrieux, P., Fricker, H. A., Holland, D., MacGregor, J., Medley, B., Nicolas, J. P., Pollard, D., Siegfried, M. R., Smith, A. M., Steig, E. J., Trusel, L. D., Vaughan, D. G., and Yager, P. L.: How much, how fast?: A science review and outlook for research on the instability of Antarctica's Thwaites Glacier in the 21st century, Global Planet. Change, 153, 16-34, https://doi.org/10.1016/j.gloplacha.2017.04.008, 2017.

Scheuchl, B., Mouginot, J., Rignot, E., Morlighem, M., and Khazendar, A.: Grounding line retreat of Pope, Smith, and Kohler Glaciers, West Antarctica, measured with Sentinel-1a radar interferometry data, Geophys. Res. Lett., 43, 8572-8579, https://doi.org/10.1002/2016GL069287, 2016.

Seehaus, T., Marinsek, S., Helm, V., Skvarca, P., and Braun, M.: Changes in ice dynamics, elevation and mass discharge of Dinsmoor-Bombardier-Edgeworth glacier system, Antarctic Peninsula, Earth Planet. Sc. Lett., 427, 125-135, https://doi.org/10.1016/j.epsl.2015.06.047, 2015.

Spence, P., Griffies, S. M., England, M. H., Hogg, A. McC., Saenko, O. A., and Jourdain, N. C.: Rapid subsurface warming and circulation changes of Antarctic coastal waters by poleward shifting winds: Antarctic subsurface ocean warming, Geophys. Res. Lett., 41, 4601-4610, https://doi.org/10.1002/2014GL060613, 2014.
Stewart, A. L., Klocker, A., and Menemenlis, D.: CircumAntarctic Shoreward Heat Transport Derived From an Eddy- and Tide-Resolving Simulation, Geophys. Res. Lett., 45, 834-845, https://doi.org/10.1002/2017GL075677, 2018.

Tedesco, M. and Monaghan, A. J.: An updated Antarctic melt record through 2009 and its linkages to high-latitude and tropical climate variability, Geophys. Res. Lett., 36, L18502, https://doi.org/10.1029/2009GL039186, 2009.

Tetzner, D., Thomas, E., and Allen, C.: A Validation of ERA5 Reanalysis Data in the Southern Antarctic Peninsula - Ellsworth Land Region, and Its Implications for Ice Core Studies, Geosciences, 9, 289, https://doi.org/10.3390/geosciences9070289, 2019.

Thoma, M., Jenkins, A., Holland, D., and Jacobs, S.: Modelling Circumpolar Deep Water intrusions on the Amundsen Sea continental shelf, Antarctica, Geophys. Res. Lett., 35, L18602, https://doi.org/10.1029/2008GL034939, 2008.

Trusel, L. D., Frey, K. E., Das, S. B., Munneke, P. K., and van den Broeke, M. R.: Satellite-based estimates of Antarctic surface meltwater fluxes: Satellite-Based Antarctic Melt Fluxes, Geophys. Res. Lett., 40, 6148-6153, https://doi.org/10.1002/2013GL058138, 2013.

Vaughan, D. G. and Doake, C. S. M.: Recent atmospheric warming and retreat of ice shelves on the Antarctic Peninsula, Nature, 379, 328-328, 1996.

Verdy, A., Marshall, J., and Czaja, A.: Sea surface temperature variability along the path of the Antarctic Circumpolar Current, J. Phys. Oceanogr., 36, 1317-1331, 2006.

Walker, C. C. and Gardner, A. S.: Rapid drawdown of Antarctica's Wordie Ice Shelf glaciers in response to ENSO/Southern Annular Mode-driven warming in the Southern Ocean, Earth Planet. Sc. Lett., 476, 100-110, https://doi.org/10.1016/j.epsl.2017.08.005, 2017.

Walker, C. C., Bassis, J. N., Fricker, H. A., and Czerwinski, R. J.: Structural and environmental controls on Antarctic ice shelf rift propagation inferred from satellite monitoring: Antarctic Ice Shelf Rifting, J. Geophys. Res.-Earth, 118, 2354-2364, https://doi.org/10.1002/2013JF002742, 2013.

Walker, C. C., Gardner, A. S., Neumann, T., Fricker, H. A., Bassis, J. N., and Paolo, F. S.: Iceberg, right ahead!: The surprising and ongoing collapse of an East Antarctic ice shelf in response to changes in the ocean environment, in: AGU Fall Meeting Abstracts, C13A-06, 2019.

Wang, G., Cai, W., and Purich, A.: Trends in Southern Hemisphere wind-driven circulation in CMIP5 models over the 21st century: Ozone recovery versus greenhouse forcing, J. Geophys. Res.-Oceans, 119, 2974-2986, https://doi.org/10.1002/2013JC009589, 2014.

Wessel, B., Huber, M., Wohlfart, C., Bertram, A., Osterkamp, N., Marschalk, U., Gruber, A., Reuß, F., Abdullahi, S., Georg, I., and Roth, A.: TanDEM-X PolarDEM 90 m of Antarctica: Generation and error characterization, The Cryosphere Discuss. [preprint], https://doi.org/10.5194/tc-2021-19, in review, 2021.

Wouters, B., Martin-Espanol, A., Helm, V., Flament, T., van Wessem, J. M., Ligtenberg, S. R. M., van den Broeke, M. R., and Bamber, J. L.: Dynamic thinning of glaciers on the Southern Antarctic Peninsula, Science, 348, 899-903, https://doi.org/10.1126/science.aaa5727, 2015. 
Wuite, J., Nagler, T., Gourmelen, N., Escorihuela, M. J., Hogg, A. E., and Drinkwater, M. R.: Sub-Annual Calving Front Migration, Area Change and Calving Rates from Swath Mode CryoSat-2 Altimetry, on Filchner-Ronne Ice Shelf, Antarctica, Remote Sens., 11, 2761, https://doi.org/10.3390/rs11232761, 2019. 